\title{
ORGANIC REAGENTS FOR SPECTROPHOTOMETRIC DETERMINATION OF ANIONS
}

\author{
Y.K. Agrawal \\ Chemistry Department, School of Sciences \\ Gujarat University, Ahmedabad - 380009 , India
}

CONTENTS

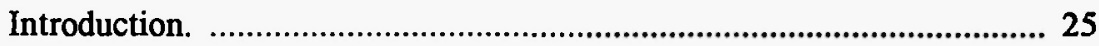

Summarizing Tables for Various Anions ............................................... 26

Frequently Used Spectrophotometric Determinations of Common

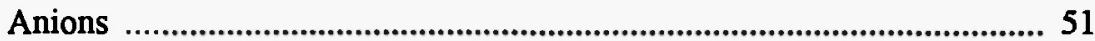

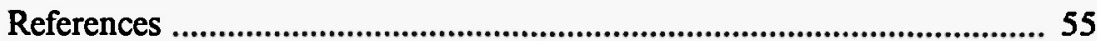

\section{INTRODUCTION}

Organic reagents have a remarkable versatility for inorganic and organic analysis. The most important among the organic reagents are those which form 'chelates' with the metal ion. The chelating agents should possess two functional groups which may be either acidic, coordinating or a combination of both. The acidic character may be due to the presence of a hydroxy $(-\mathrm{OH})$, mecapto $(-\mathrm{SH})$, or imino $(=\mathrm{NH})$ group, including forms such as enol ( $\mathrm{HOC}=\mathrm{CH}-$ ), oxime $(=\mathrm{N}-\mathrm{OH})$, acid nitro $(=\mathrm{N}-\mathrm{OH})$, sulphinic $(-\mathrm{SO}-\mathrm{OH})$, sulphonic $\left(-\mathrm{SO}_{2}-\mathrm{OH}\right)$ or their thio analogue. On the other hand, groups like carbonyl $(>\mathrm{C}=\mathrm{O})$, thio $(>\mathrm{C}=\mathrm{S})$, primary amino $(-\mathrm{NH})$, secondary amino $\left(-\mathrm{NH}_{2}\right)$ or tertiary amino $\left(-\mathrm{NR}^{\prime}\right)$, nitrosyl (-NO), etc. coordinate by virtue of the lone pair of electrons on the $\mathrm{N}, \mathrm{S}$ or $\mathrm{O}$ atoms. Systematical study of organic reagents containing the aforesaid groups for the development of analytical methods for anions is scanty. Generally the organic reagents have been used widely for anions by indirect methods, either forming ion pair complexes or adding to the metal complexes to make metal chelates, from which the anion concentration is determined. A large number of organic reagents have been used for the extraction spectrophotometric determination 
of several anions. The use of organic reagents for the determination of various anions has been summarised in Tables $1-8 / 1-254 /$. Some frequently used spectrophotometric methods for the most common anions are discussed in the subsequent paragraphs.

\section{SUMMARIZING TABLES FOR VARIOUS ANIONS}

In Tables 1-8, the following abbreviations are used:

\begin{tabular}{|c|c|c|c|}
\hline $\mathrm{Ac}_{2} \mathrm{O}$ & Acetic anhydride & EtOH & Ethyl alcohol \\
\hline $\mathrm{AcOH}$ & Acetic acid & ex & excitation wavelength \\
\hline BG & Brilliant Green & HDTMA & hexadecyl trimethyl \\
\hline BPG & Bromopyrogallol & & ammonium \\
\hline $\mathrm{BuAc}$ & Butyl acetate & IAA & Isoamyl alcohol \\
\hline iBuAc & Isobutylacetate & MB & Methylene Blue \\
\hline $\mathrm{CA}$ & Chromotropic acid & $\mathrm{Me}$ & Methyl \\
\hline CAS & Chrome Azurol S & $\mathrm{Me}_{2} \mathrm{CO}$ & Acetone \\
\hline $\mathrm{CP}$ & Cetyl pyridinium & $\mathrm{MePh}$ & Toluene \\
\hline $\mathrm{CPB}$ & Cetyl pyridinium bromide & MG & Malachite Green \\
\hline $\mathrm{CPC}$ & Cetyl pyridinium chloride & MIBK & Methyl isobutyl ketone \\
\hline CTMA & Cetyl trimethyl & MTB & Methyl Thymol Blue \\
\hline $\mathrm{CV}$ & $\begin{array}{l}\text { ammonium } \\
\text { Crystal Violet }\end{array}$ & NaHMP & $\begin{array}{l}\text { Sodium hexametaphos- } \\
\text { phate }\end{array}$ \\
\hline \multirow[t]{2}{*}{ D2EHP } & bis (2-ethyl hexyl) & $\mathrm{OAc}^{\circ}$ & Acetate \\
\hline & phosphate & PAR & 4,2-pyridylazoresorcinol \\
\hline DMF & Dimethylformamide & $\mathrm{PhCl}$ & Chlorobenzene \\
\hline DMSO & Dimethyl sulfoxide & Phen & 1,10, phenanthroline \\
\hline EBT & Eriochrome Black T & PV & Pyrocatechol Violet \\
\hline ECAB & Eriochrome Azurol B & SPACA & 3-(4-sulphophenylazo) \\
\hline ECR & Eriochrome Cyanin R & & chromotropic acid \\
\hline \multirow[t]{2}{*}{ EDTA } & Ethylenediaminetetracetic & TBP & Tri(n) butyl phosphate \\
\hline & acid disodium salt & TOA & Trioctyl amine \\
\hline em & emission wavelength & TOMA & Trioctyl methyl \\
\hline ETAc & Ethyl acetate & & ammonium \\
\hline $\mathrm{Et}_{2} \mathrm{O}$ & Diethyl ether & XO & Xylenol Orange \\
\hline
\end{tabular}




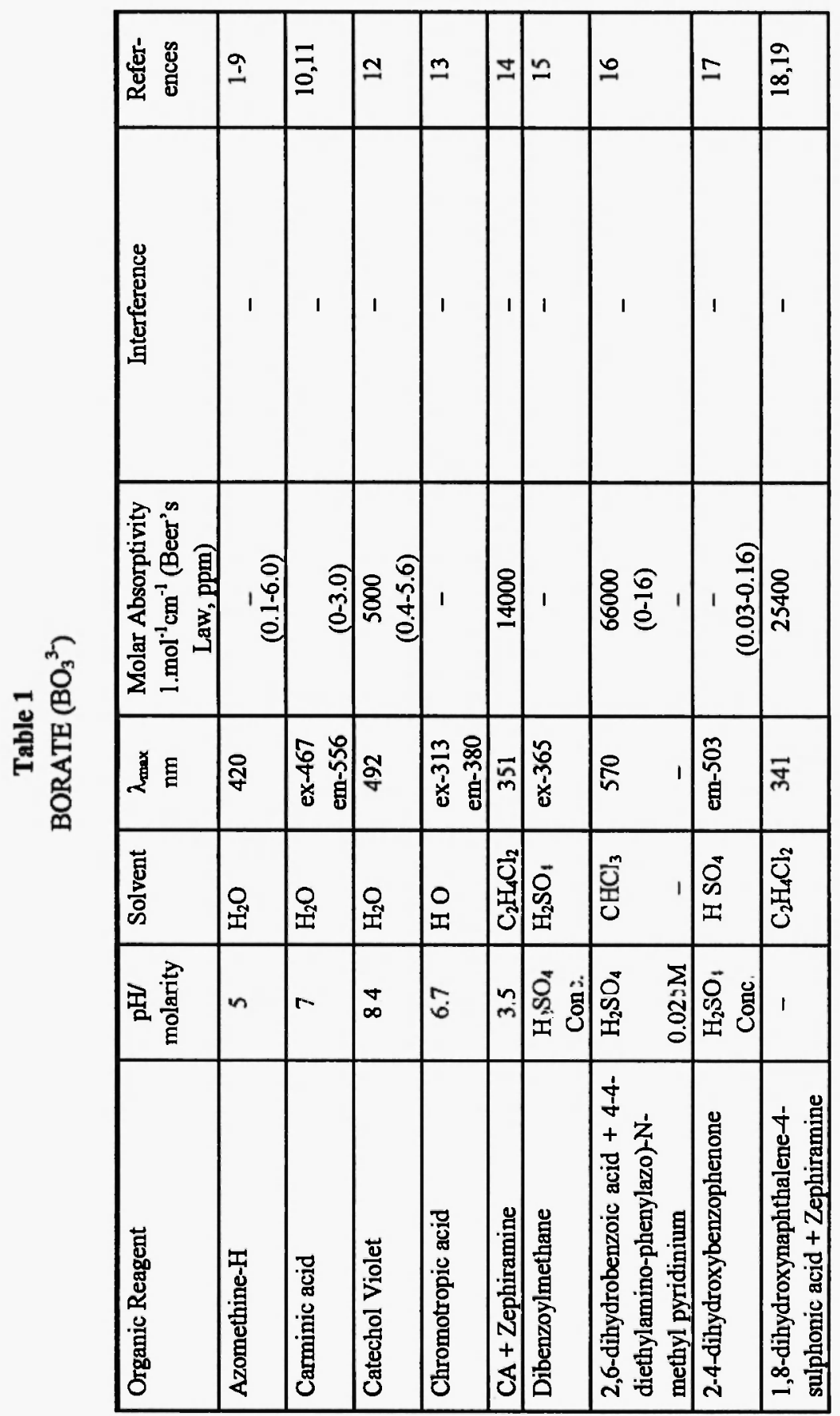




\begin{tabular}{|c|c|c|c|c|c|c|c|}
\hline 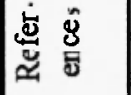 & तू & సิ & ম & ஸి & 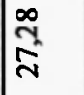 & กิ & $m$ \\
\hline 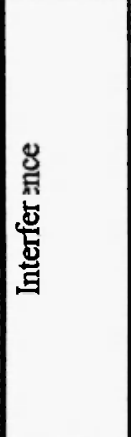 & 1 & 1 & 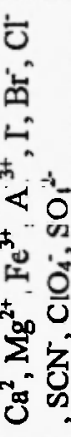 & 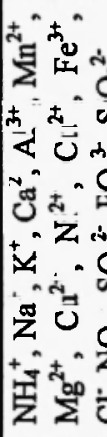 & 1 & 1 & 1 \\
\hline 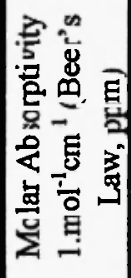 & ర্లি & 1 & 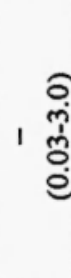 & 1 & $1 \frac{2}{8}$ & 웅 & 1 \\
\hline 鄫自 & 1 & $\curvearrowleft$ & 8 & $\stackrel{\infty}{n}$ & 1 & 음 & 总 \\
\hline : & 竞 & 원 & 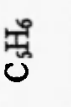 & 頱 & O্ঠ & Dू & 역 \\
\hline 鼠总 & 这 & 1 & 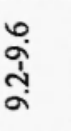 & 1 & 1 & ọ & 1 \\
\hline 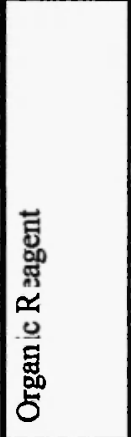 & 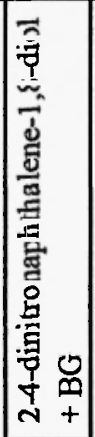 & 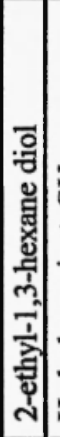 & 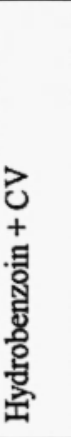 & 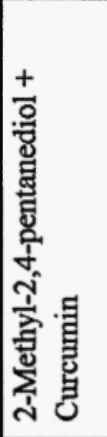 & 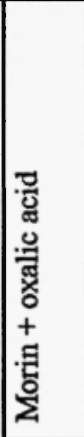 & 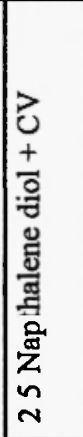 & 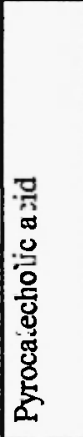 \\
\hline
\end{tabular}




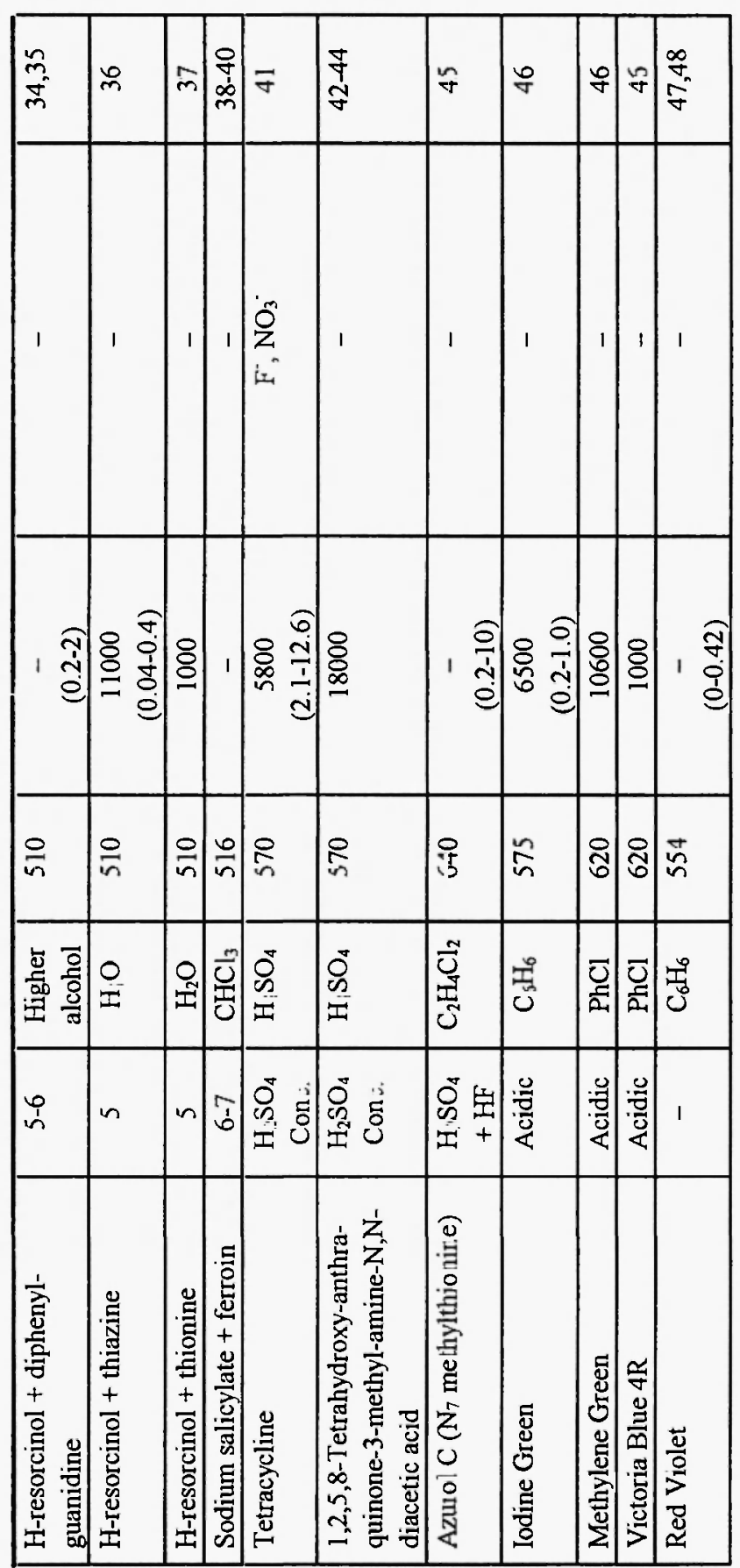




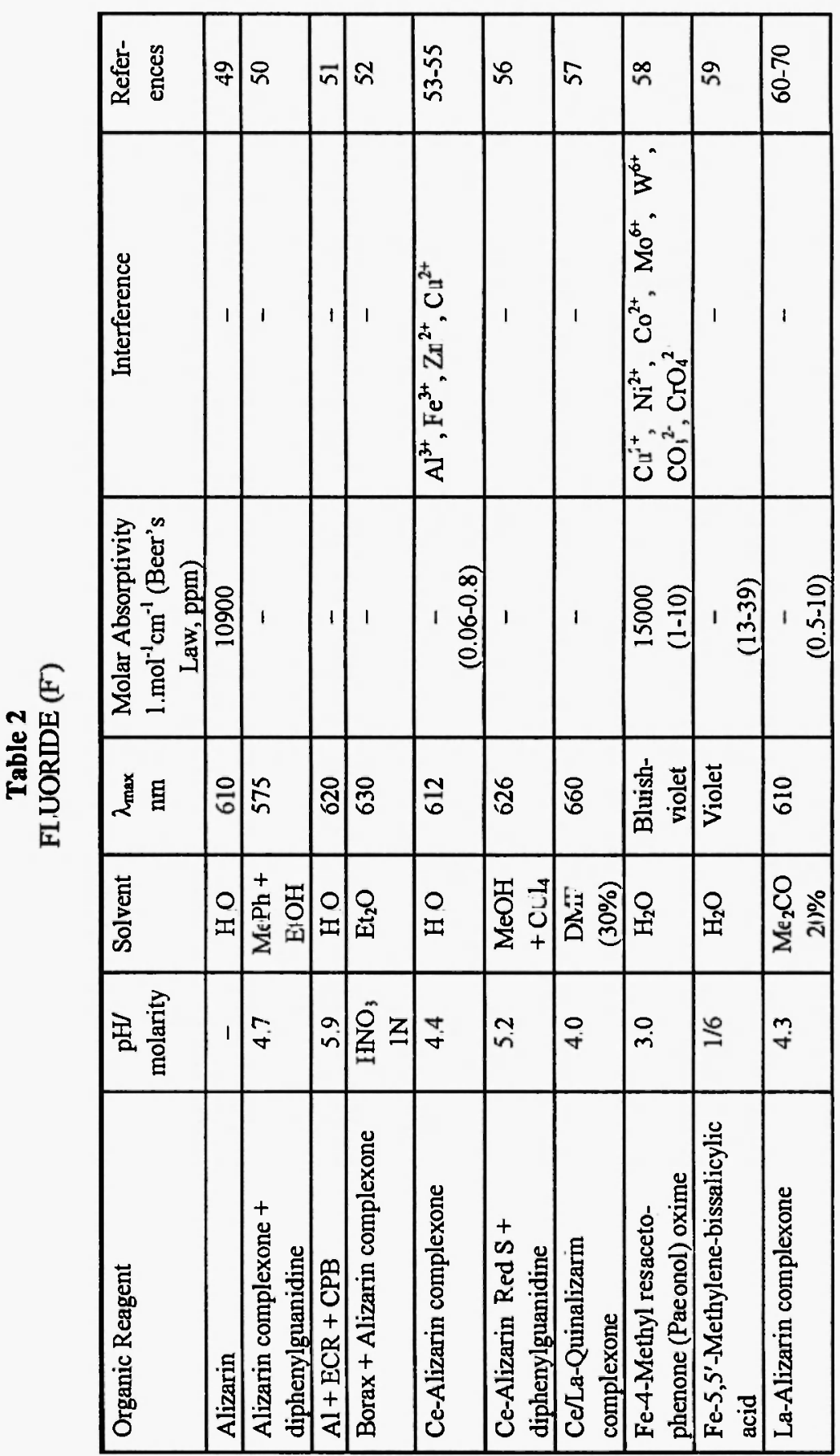




\begin{tabular}{|c|c|c|c|c|c|c|c|c|c|c|c|c|c|}
\hline$F$ & I & 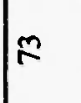 & 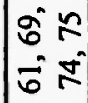 & $\left|\begin{array}{l}0 \\
0 \\
0 \\
\vdots \\
2\end{array}\right|$ & $\bar{\infty}$ & |ळ & $\infty$ & $\Phi$ & $1 \infty$ & $\begin{array}{l}\infty \\
\hat{0} \\
\dot{\infty}\end{array}$ & 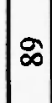 & ৪) & $\bar{a}$ \\
\hline 1 & 1 & 1 & 1 & & 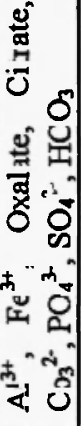 & 1 & 1 & 1 & 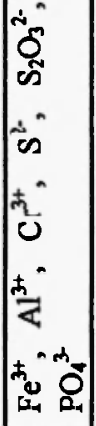 & & & $\begin{array}{l}1 \\
3 \\
3 \\
-1 \\
\oplus \infty\end{array}$ & 1 \\
\hline 1 & 1 & 1 & 1 ठิ่ & & 1 웅 & 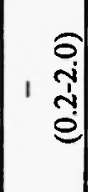 & \&్రి & 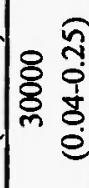 & $\begin{array}{l}\text { 1 } \\
\text { 1 } \\
\text { c }\end{array}$ & $\begin{array}{l}3 \\
1 \\
1 \\
0 \\
0 \\
0\end{array}$ & $\begin{array}{l}8 \\
8 \\
0\end{array}$ & 氕 & 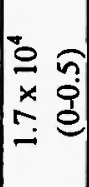 \\
\hline 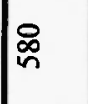 & $\approx \tilde{\sigma}$ & $\mathcal{E}$ & 染 & 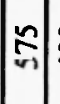 & \& & స్ูิ & $\because \check{8}$ & 영 & 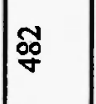 & 禺 & 1 & & $\tilde{\widehat{\sigma}}$ \\
\hline 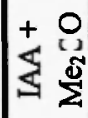 & $\mathbb{5}$ & 兽 & 条 & 일 & 역 & 条 & $\mid \begin{array}{l}0 \\
\text { II }\end{array}$ & 送 & 足 & 茎 & 1 & 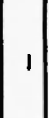 & 它 o \\
\hline$\stackrel{m}{q}$ & $\stackrel{m}{q}$ & 1 & مُ & 1 & nे & ర్తు & 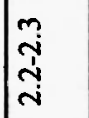 & 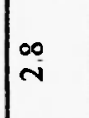 & $\overline{\underline{U}}$ & 9 & 1 & 웁 & $\begin{array}{l}0 \\
0 \\
0 \\
0 \\
0 \\
\dot{m}\end{array}$ \\
\hline 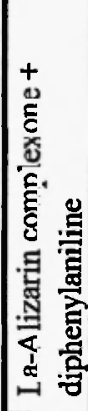 & 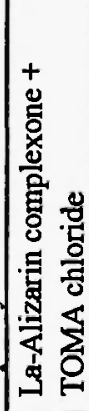 & 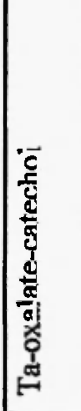 & 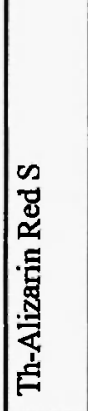 & 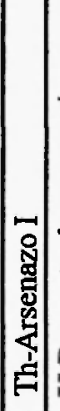 & 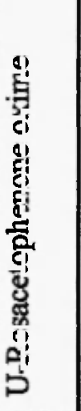 & 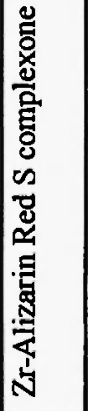 & 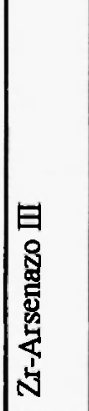 & 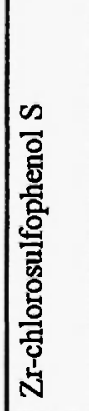 & 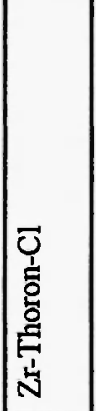 & $\mid \begin{array}{l}0 \\
1 \\
\vdots \\
\vdots\end{array}$ & 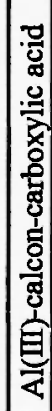 & |련 & 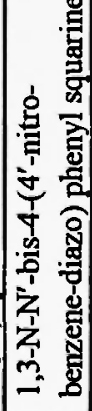 \\
\hline
\end{tabular}




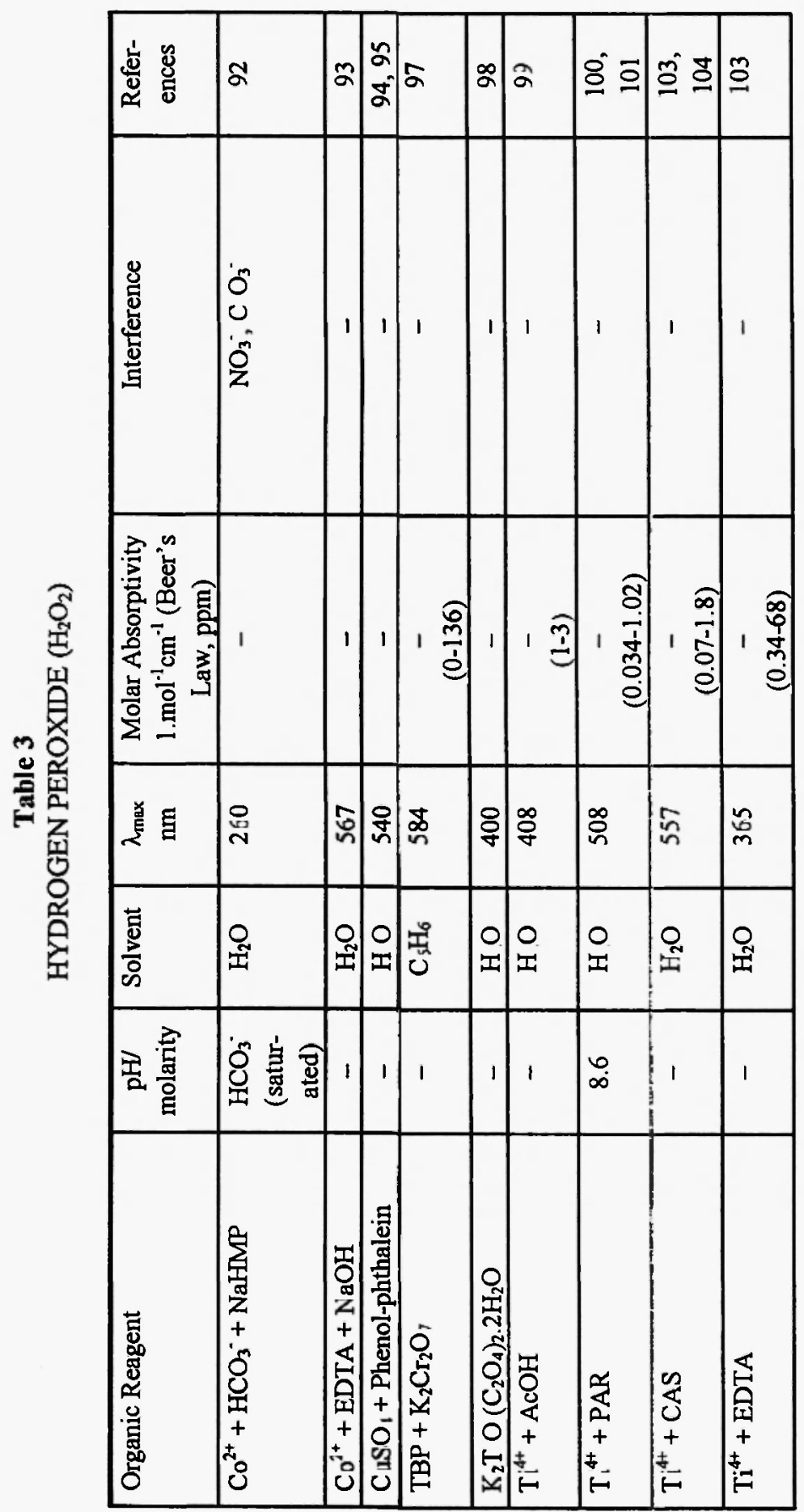




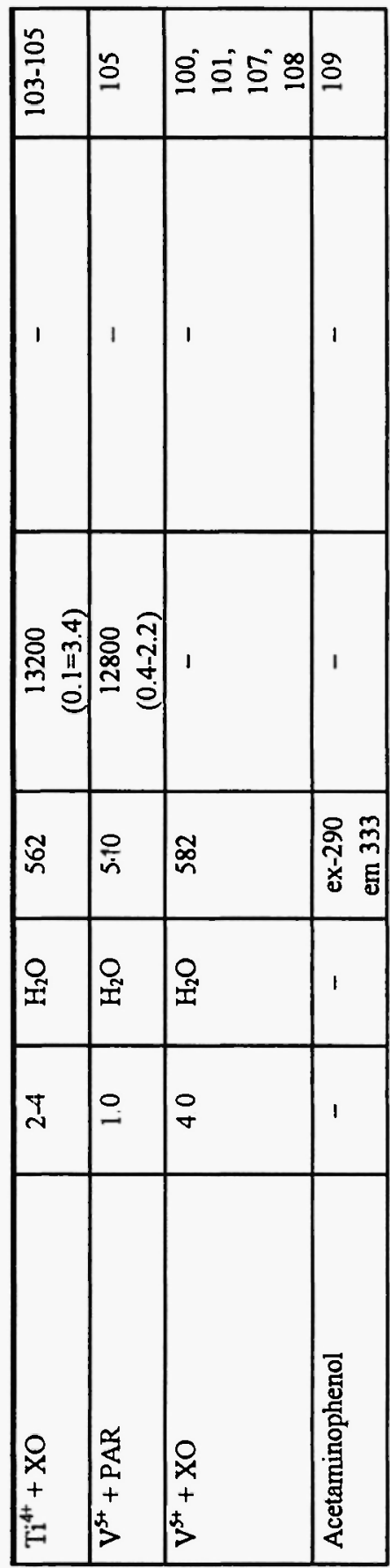




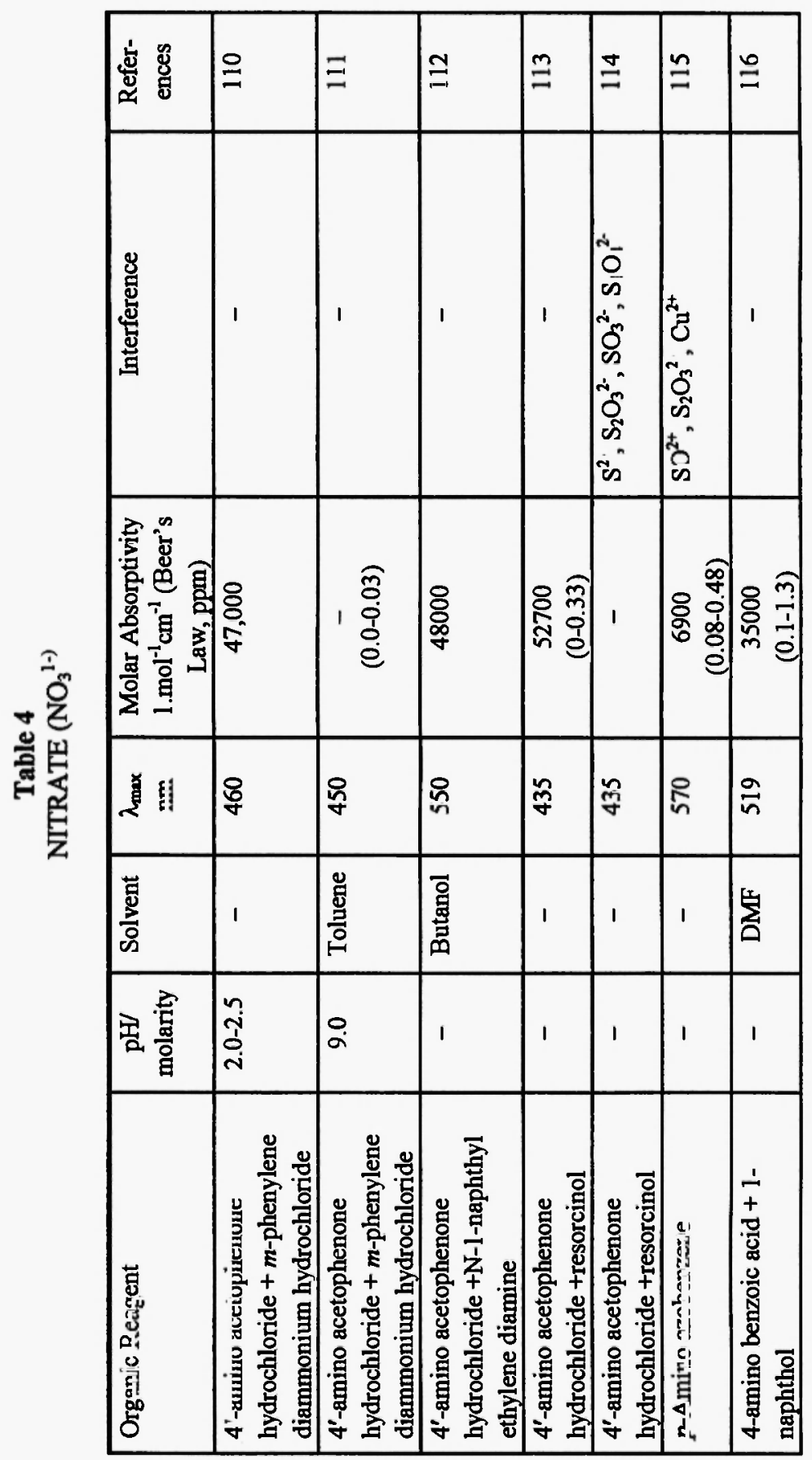




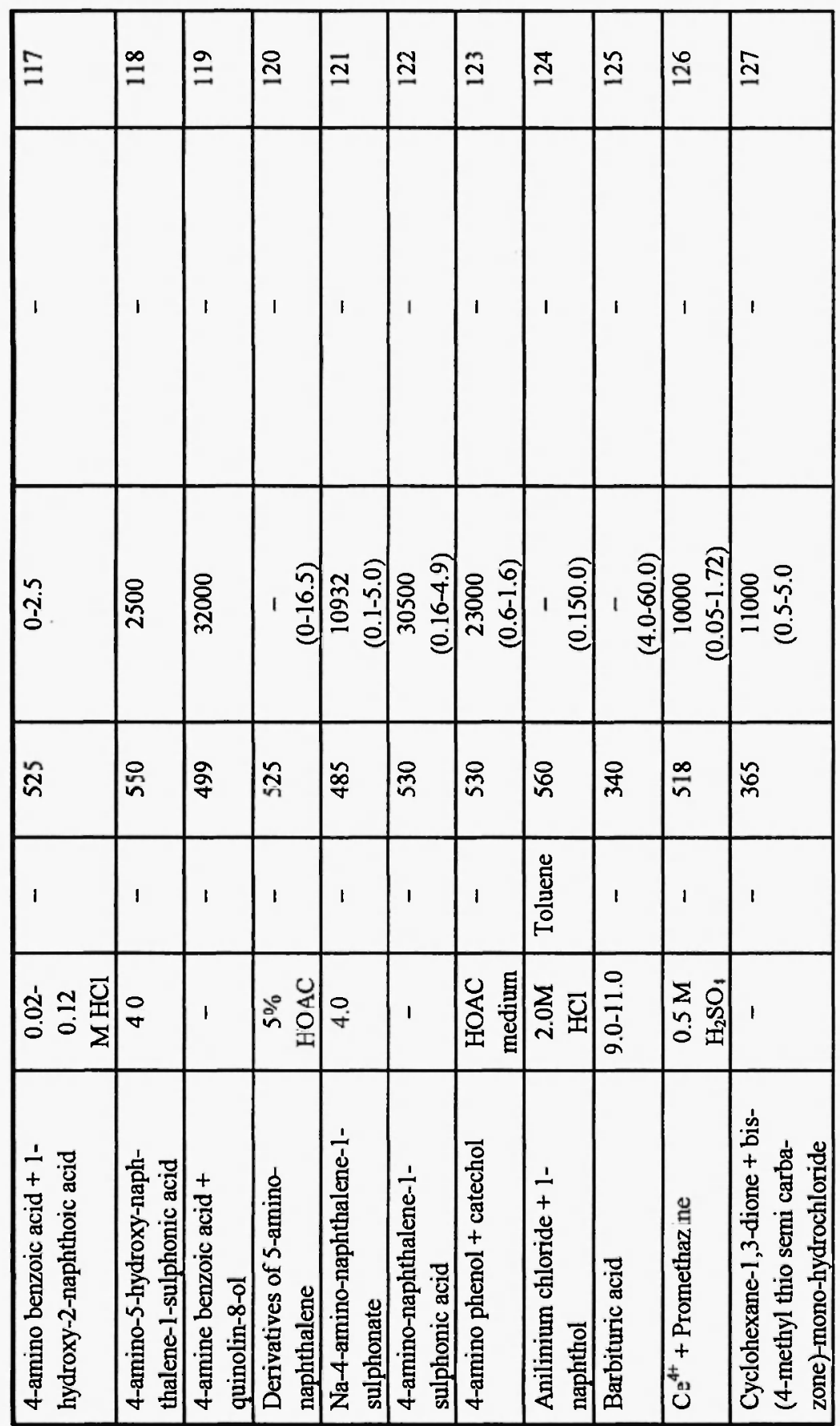




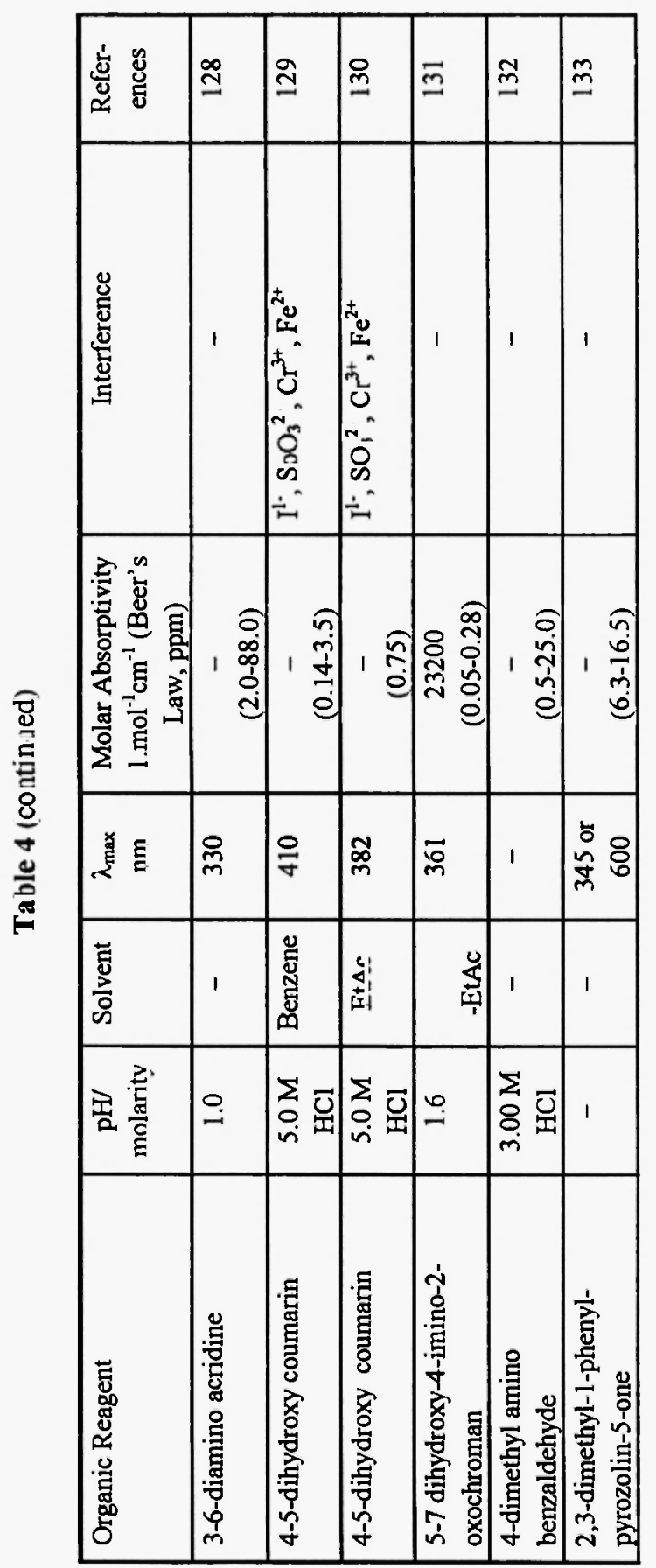




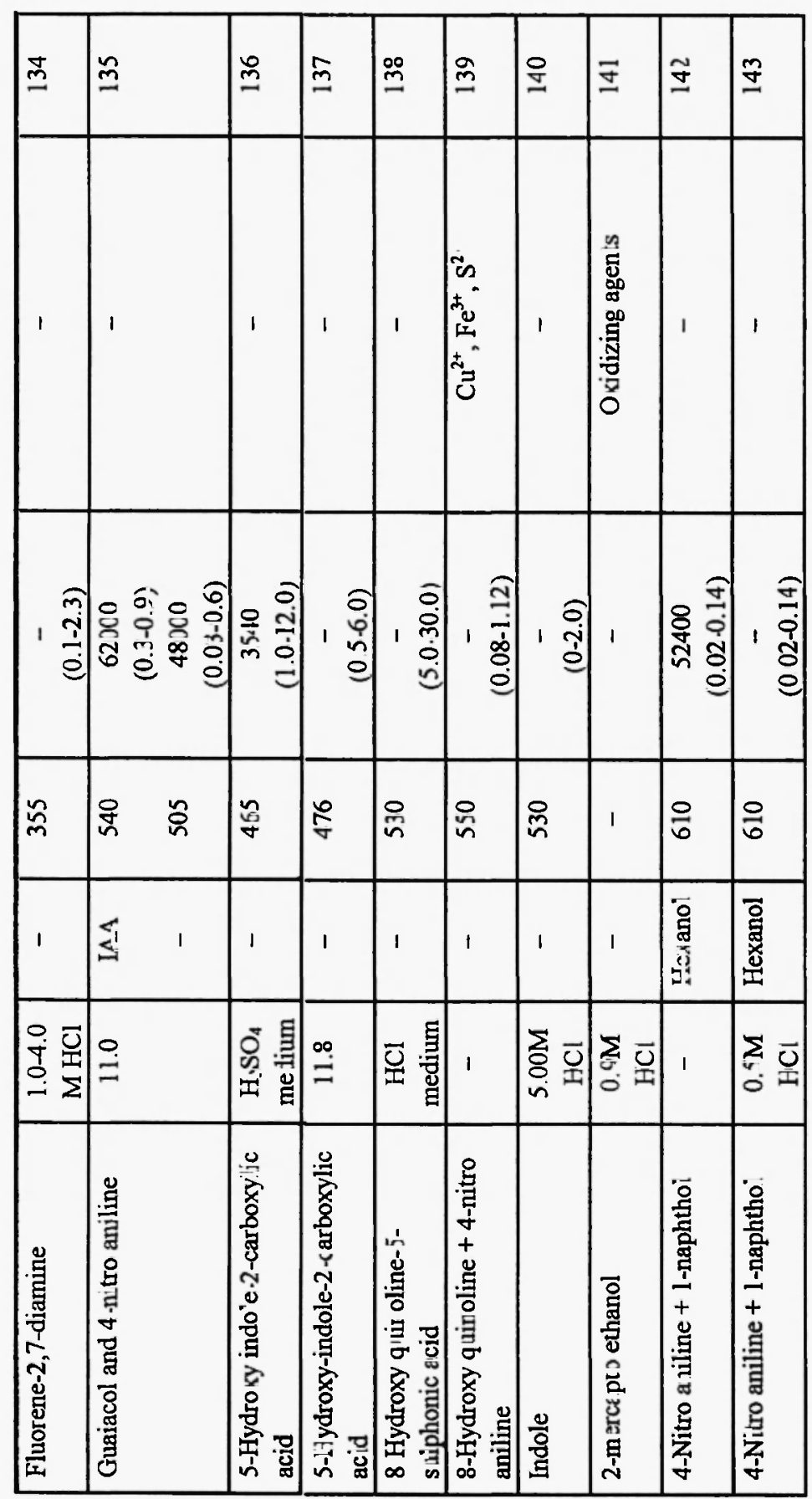




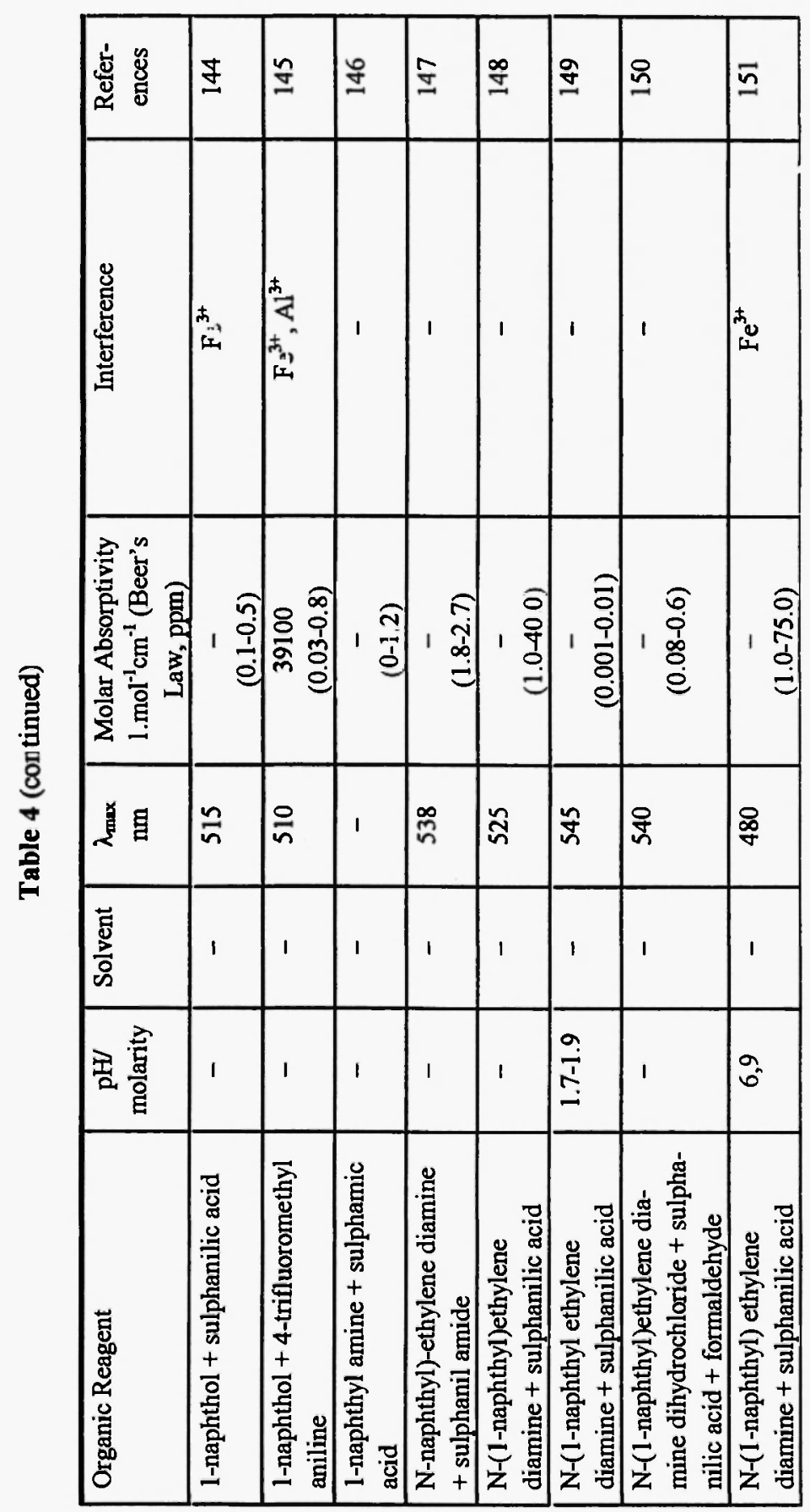




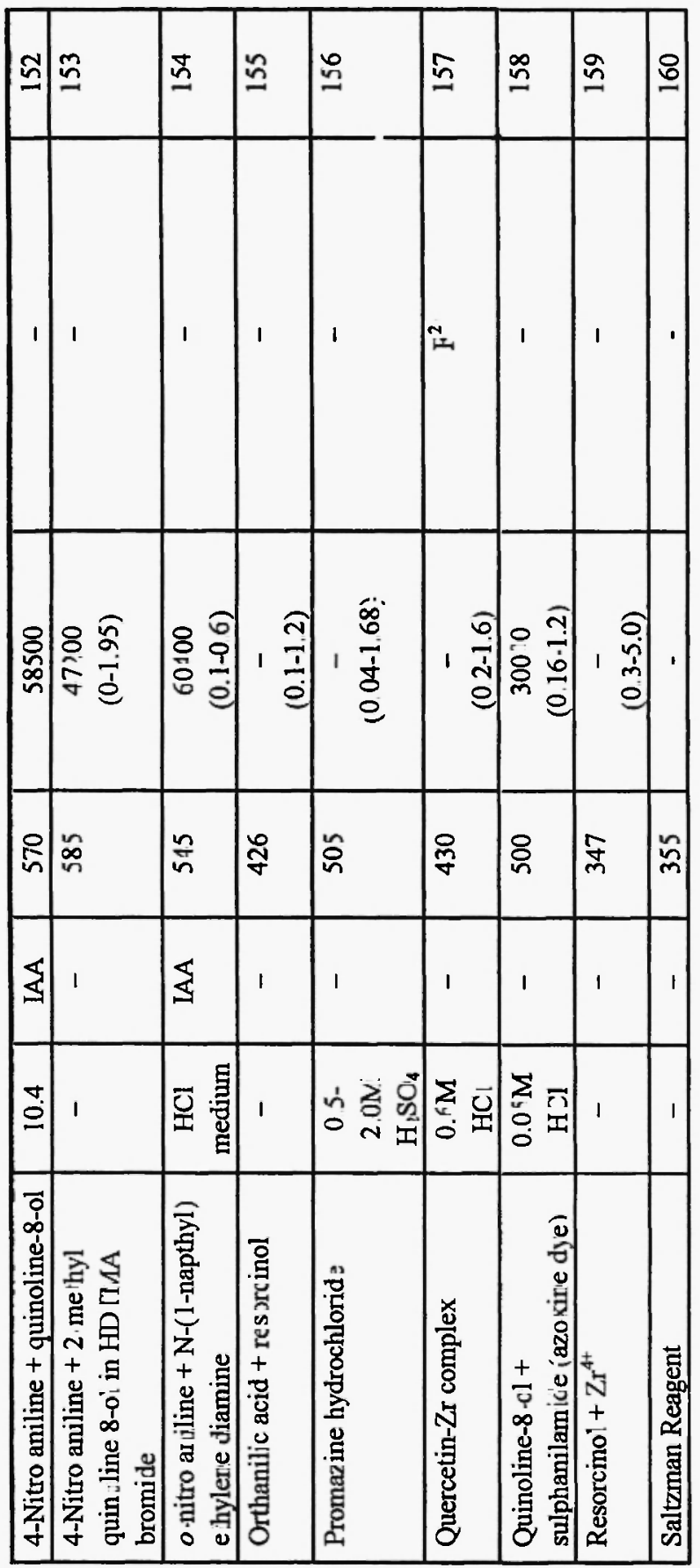




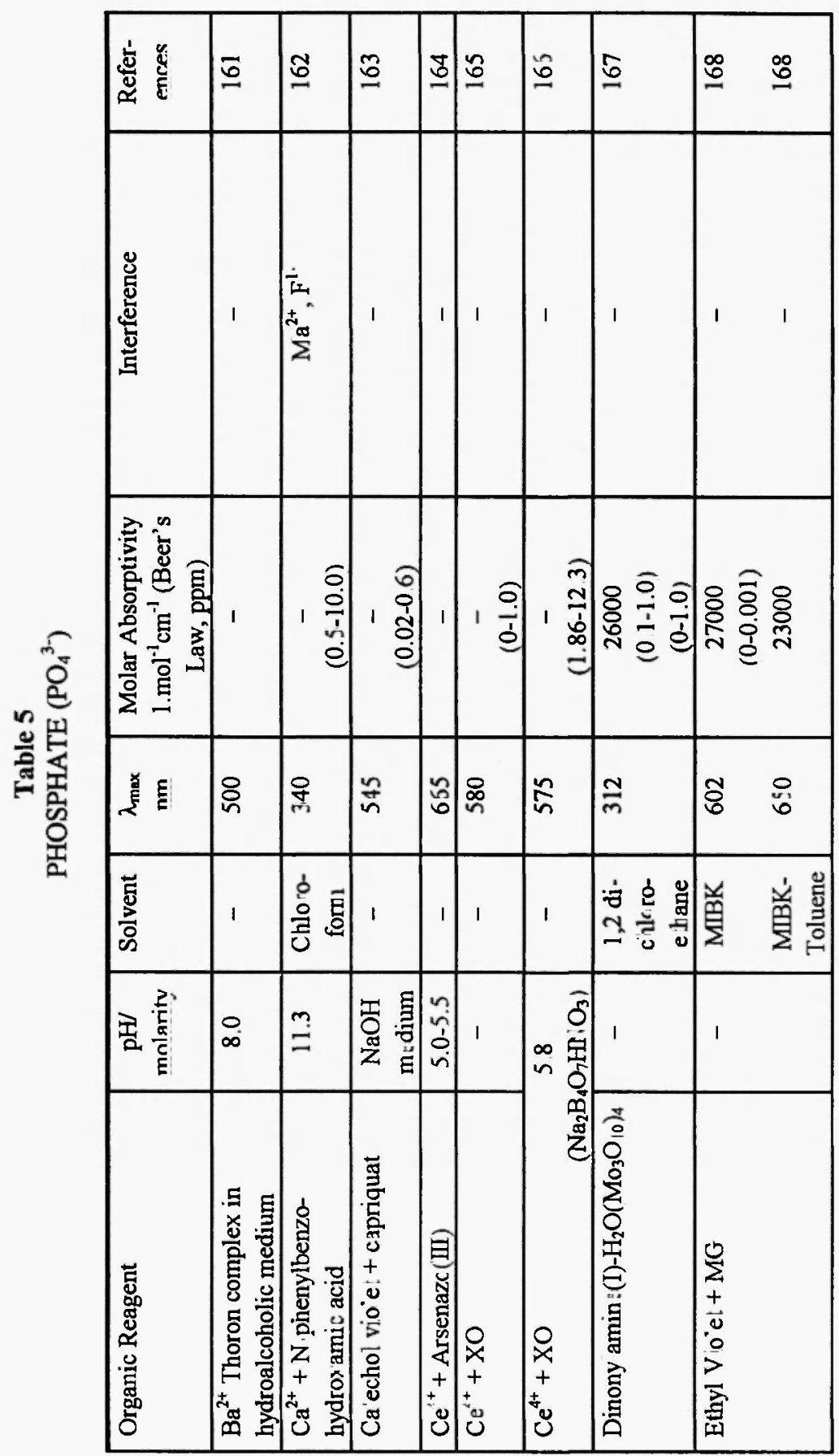




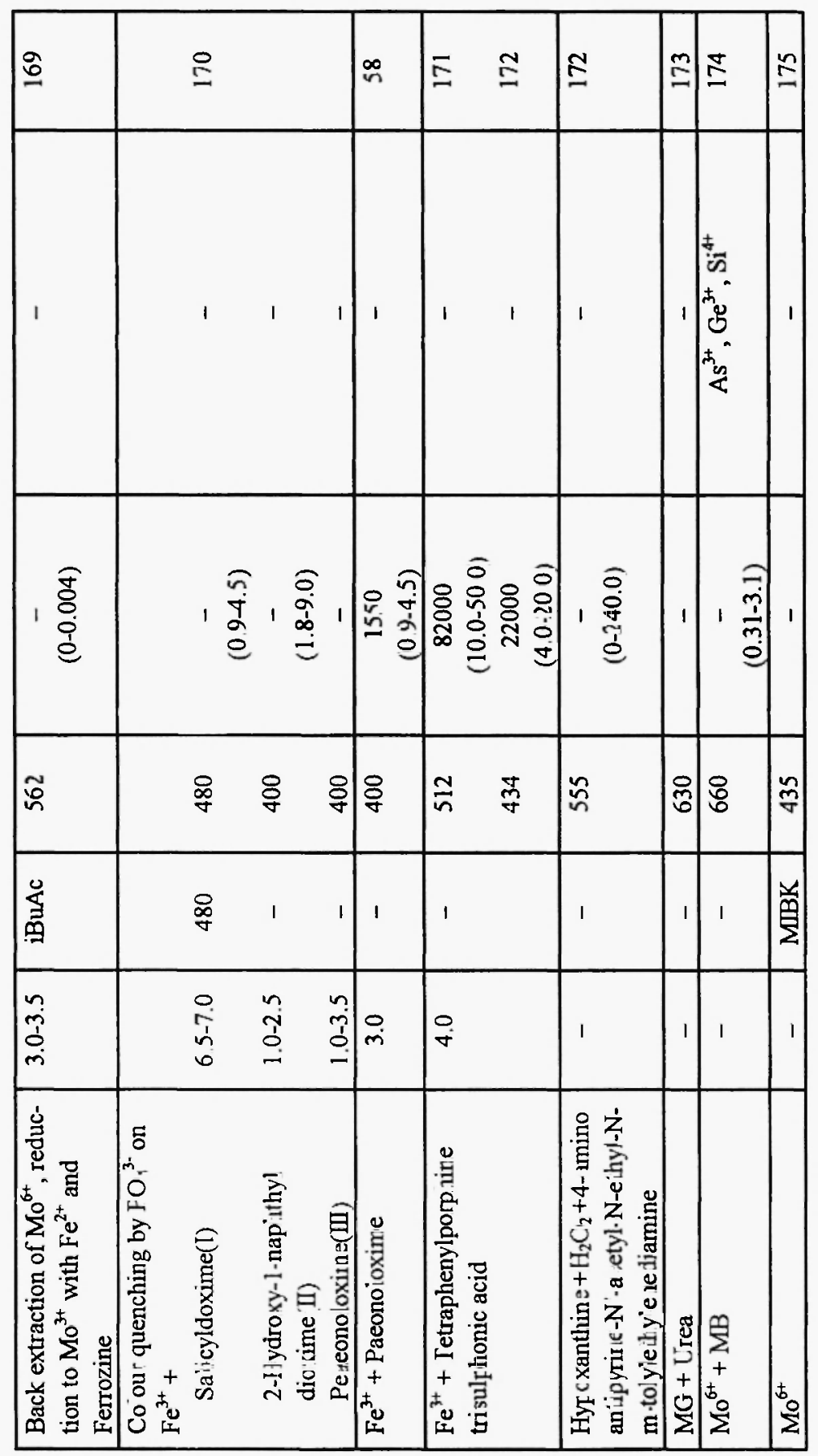




\begin{tabular}{|c|c|c|c|c|c|c|c|c|c|}
\hline 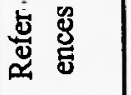 & 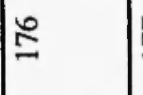 & 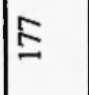 & $\stackrel{\infty}{=}$ & I & $\stackrel{\infty}{-}$ & $\underset{\infty}{\infty}$ & $\infty$ & $\stackrel{\infty}{\infty}$ & 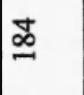 \\
\hline 总 & 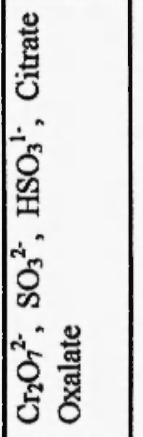 & 1 & 1 & 1 & 1 & 1 & 1 & 1 & 1 \\
\hline 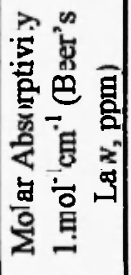 & $\frac{m}{1}$ & 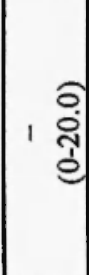 & 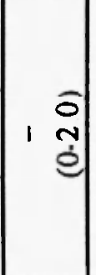 & 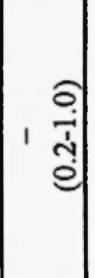 & 1 & 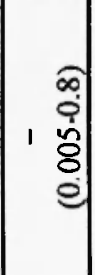 & $\begin{array}{ll} & 0 \\
& 0 \\
1 & 0 \\
0 & 0\end{array}$ & 1 & 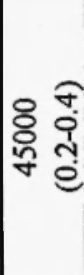 \\
\hline 曾目 & $\approx$ & 욤 & $\underset{\infty}{\infty}$ & $\underset{\infty}{\infty}$ & 을 & \& & 유 & \&্ণ & $\stackrel{\infty}{\not}$ \\
\hline 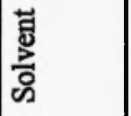 & 1 & 1 & 1 & 1 & 1 & 1 & 1 & 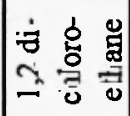 & 1 \\
\hline 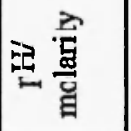 & 离 & 1 & 1 & 웅 & 1 & 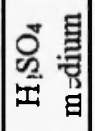 & 总 & 움 & 究 \\
\hline 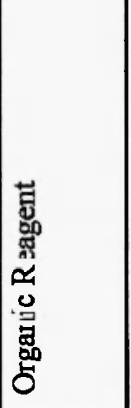 & 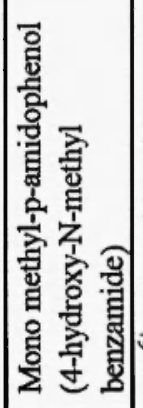 & 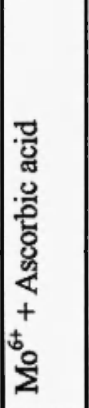 & 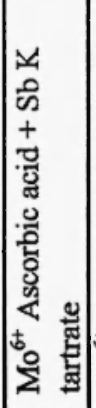 & 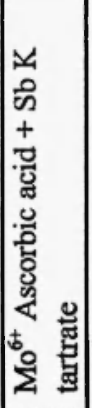 & 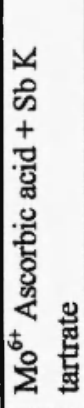 & 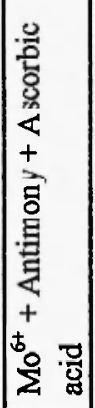 & 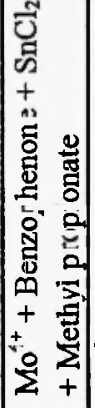 & 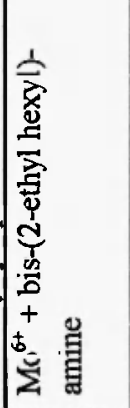 & 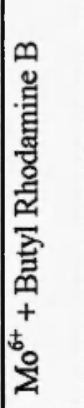 \\
\hline
\end{tabular}




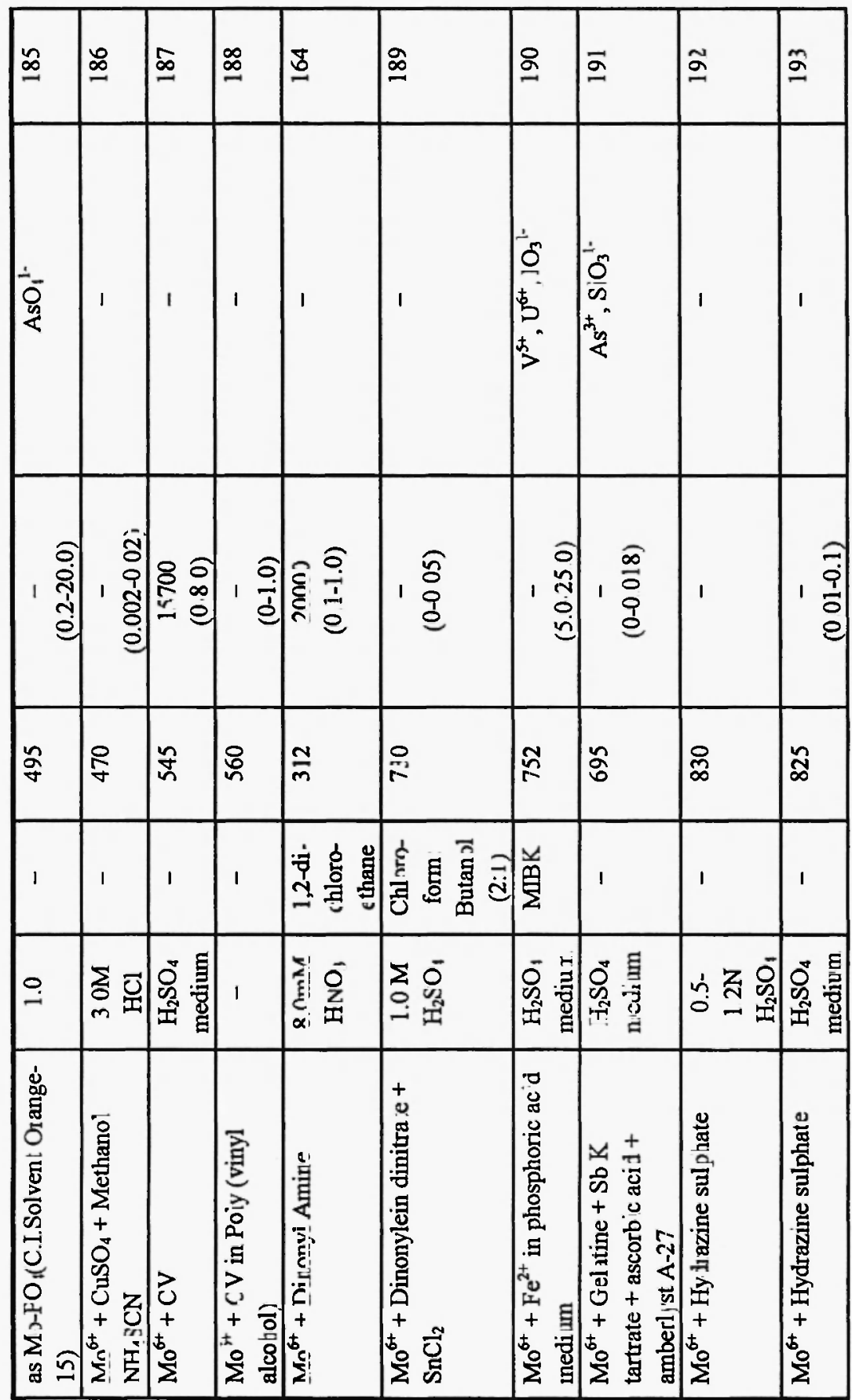




\begin{tabular}{|c|c|c|c|c|c|c|c|}
\hline 岂 导 & $\Xi$ & $\approx$ & 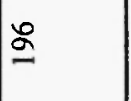 & $\hat{\Omega}$ & $\stackrel{\circ}{\stackrel{一}{2}}$ & ஓ & i্ণ \\
\hline 苞 & 1 & 1 & 1 & 1 & 1 & 1 & 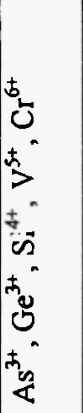 \\
\hline 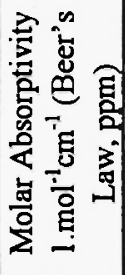 & $\begin{array}{ll} & \circ \\
1 & \stackrel{7}{2} \\
\text { ò }\end{array}$ & $\begin{array}{l}0 \\
0 \\
1 \\
0 \\
8 \\
0\end{array}$ & 1 & 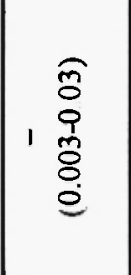 & 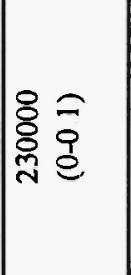 & $\mid \begin{array}{ll}8 & 0 \\
8 & 1 \\
8 & 1 \\
0 & 0\end{array}$ & $\begin{array}{l}0 \\
1 \\
1 \\
1 \\
1 \\
0 \\
0 \\
0\end{array}$ \\
\hline 㞼 芫 & $\frac{O}{m}$ & 융 & సু & సু & 周 & 옹 & 告 \\
\hline$\frac{\overrightarrow{0}}{8}$ & 을 & 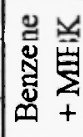 & ن 宽 & 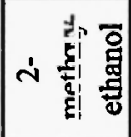 & 离学 & 1 & 首 \\
\hline 空空 & ত & $\begin{array}{l}\overline{0} \\
0 \\
1\end{array}$ & I & 吕罭 & 1 & $\begin{array}{l}0 \\
\dot{p} \\
0 \\
i j\end{array}$ & 完矛 \\
\hline 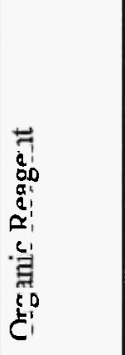 & $\begin{array}{l}\bar{u} \\
\dot{y} \\
+ \\
+ \\
b^{0}\end{array}$ & $\mid \begin{array}{l}0 \\
\Sigma \\
+ \\
+ \\
0 \\
\Sigma\end{array}$ & $\begin{array}{l}0 \\
\sum \\
+ \\
5 \\
0 \\
\sum\end{array}$ & $\mid \begin{array}{l}0 \\
\Sigma \\
+ \\
+1 \\
\vdots \\
\Sigma\end{array}$ & $\begin{array}{l}0 \\
\Sigma \\
+ \\
+ \\
+0 \\
\Sigma\end{array}$ & 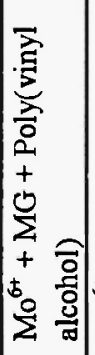 & $\begin{array}{l}n \\
\sum \\
+ \\
+ \\
\vdots \\
\vdots\end{array}$ \\
\hline
\end{tabular}




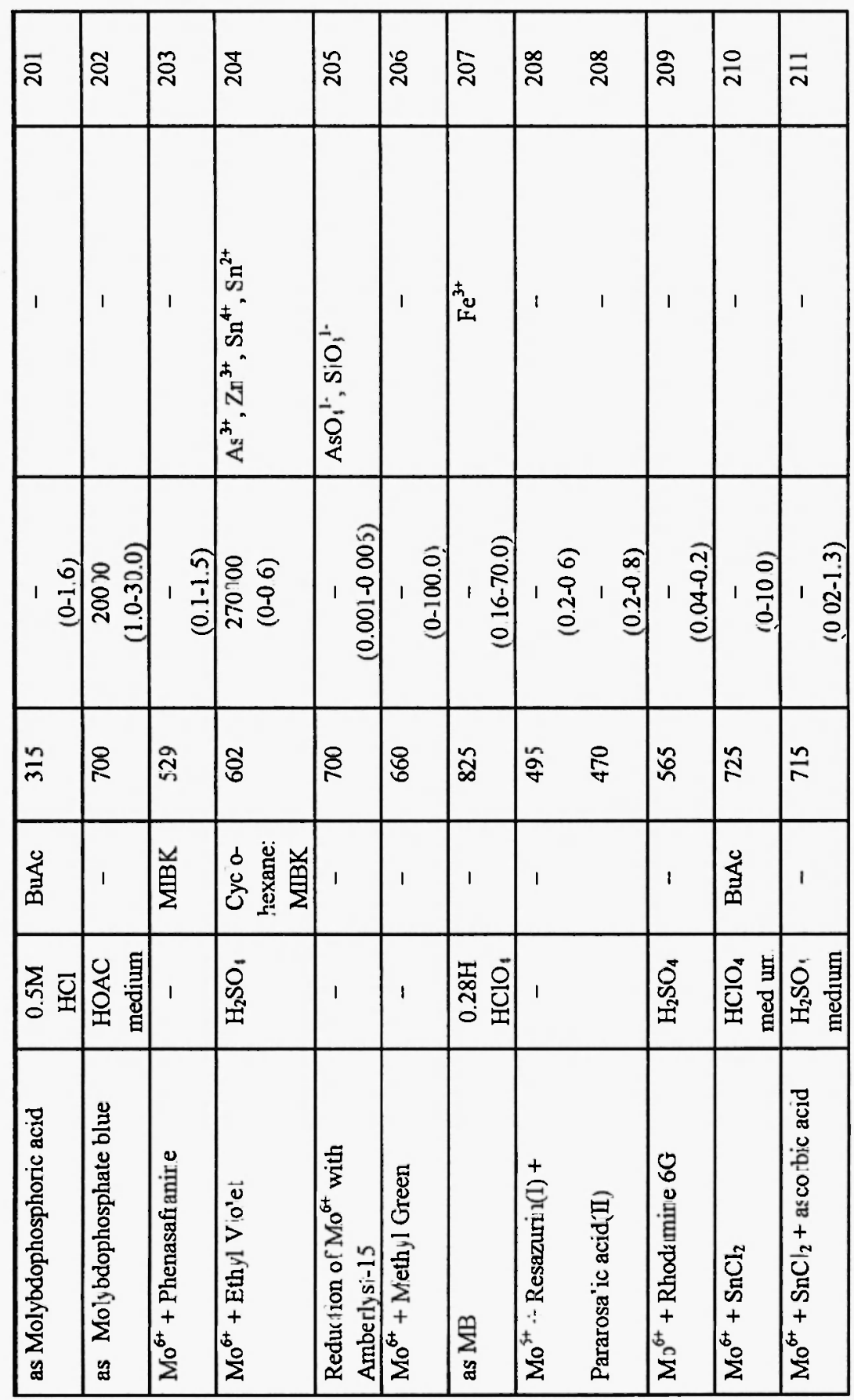


Vol. XVI, No. 1, 1997

Organic Reagents for Spectrophotometric

Determination of Anions

\begin{tabular}{|c|c|c|c|c|c|c|c|}
\hline 岕 岕 & $\stackrel{\simeq}{\sim}$ & $\stackrel{m}{\sim}$ & $\frac{\Delta}{\sim}$ & $\frac{n}{2}$ & $\stackrel{0}{2}$ & $\stackrel{\approx}{\sim}$ & $\stackrel{\infty}{\sim}$ \\
\hline 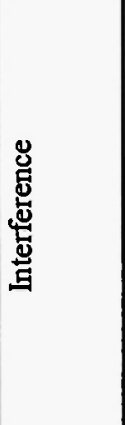 & 1 & 1 & 1 & 1 & 1 & 1 & 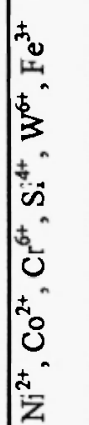 \\
\hline 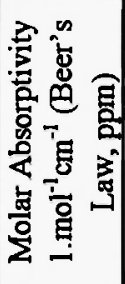 & 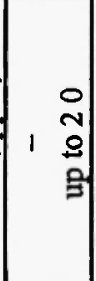 & 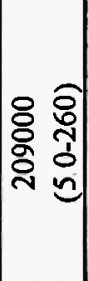 & 1 & $\begin{array}{ll} & 0 \\
1 & 8 \\
1 & 0 \\
0\end{array}$ & 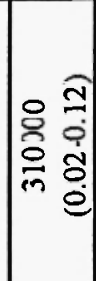 & 1 & 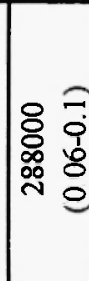 \\
\hline 总 & 융 & ন্লি & $\frac{0}{7}$ & 요 & 욤 & \& & 융 \\
\hline $\begin{array}{l}\overrightarrow{5} \\
\dot{8} \\
\text { क }\end{array}$ & 1 & 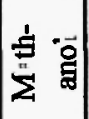 & 1 & 1 & 芹 & 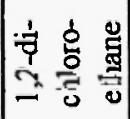 & 1 \\
\hline 疍 & 1 & in & 㲘 & 도유 & $\begin{array}{ll}\sum_{4} & \overline{0} \\
0 & \end{array}$ & 1 & \\
\hline 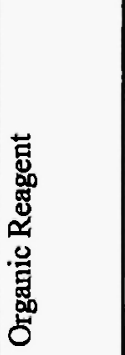 & 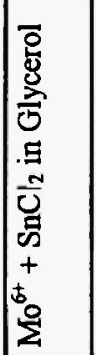 & 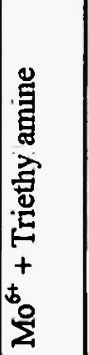 & $\begin{array}{l}5 \\
\frac{5}{5} \\
+ \\
+ \\
\text { to } \\
\stackrel{2}{\Sigma}\end{array}$ & 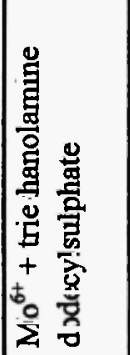 & $\begin{array}{l}3 \\
0 \\
+ \\
\pm \\
3 \\
+ \\
\text { to } \\
\vdots \\
2\end{array}$ & 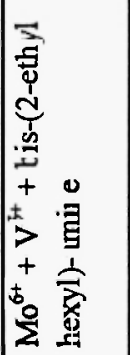 & 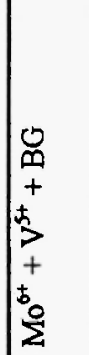 \\
\hline
\end{tabular}




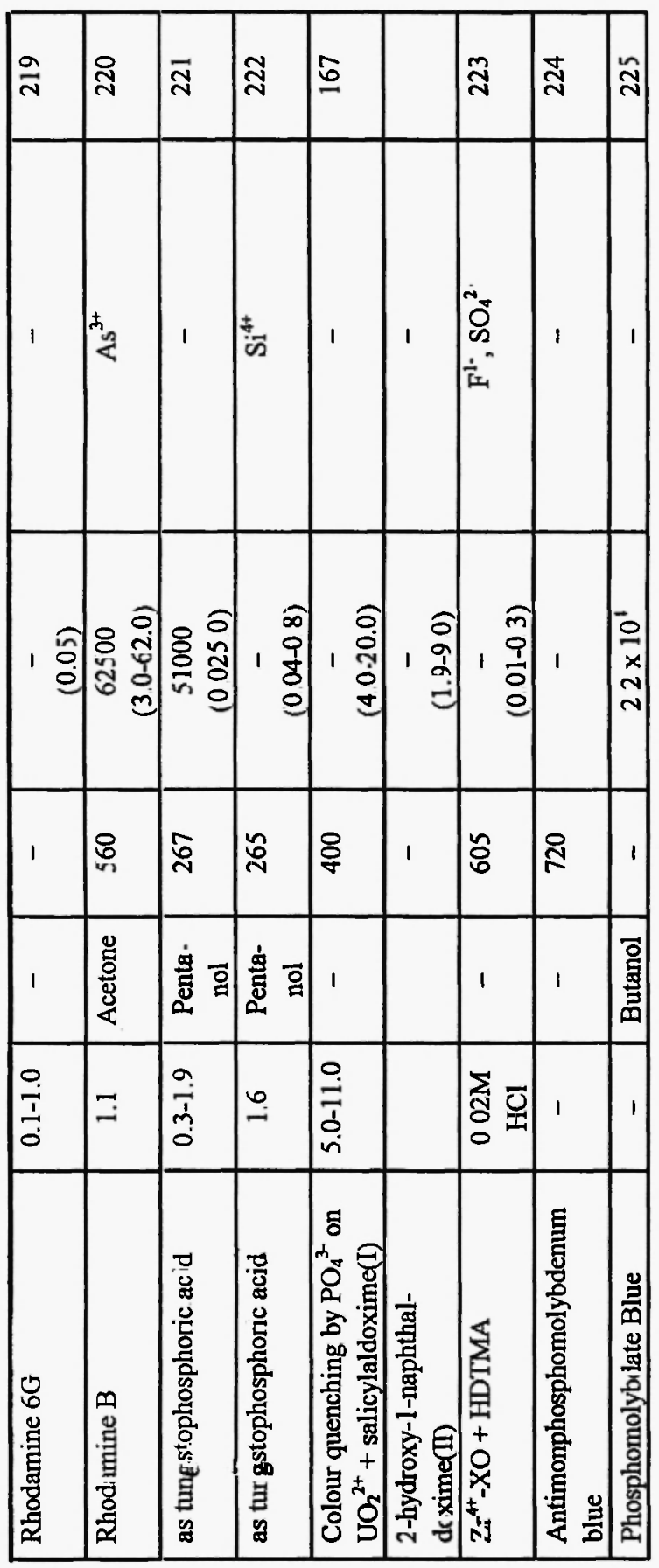


Vol. XVI, No. 1, 1997

Organic Reagents for Spectrophotometric

Determination of Anions

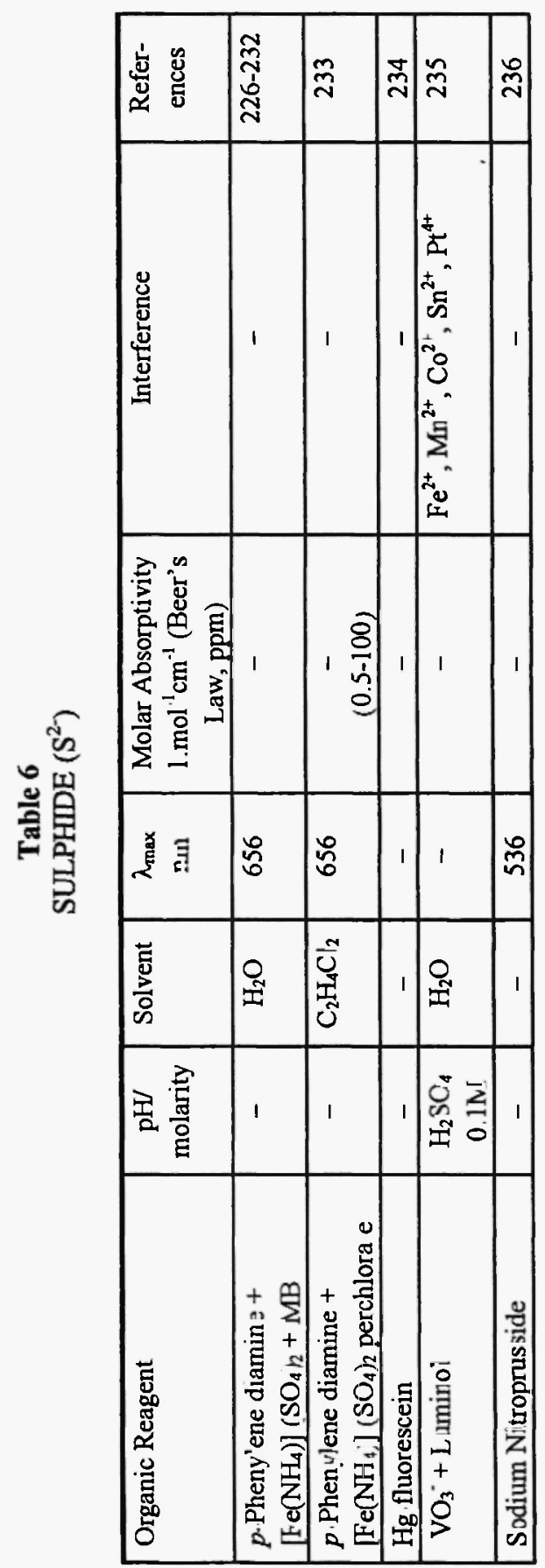




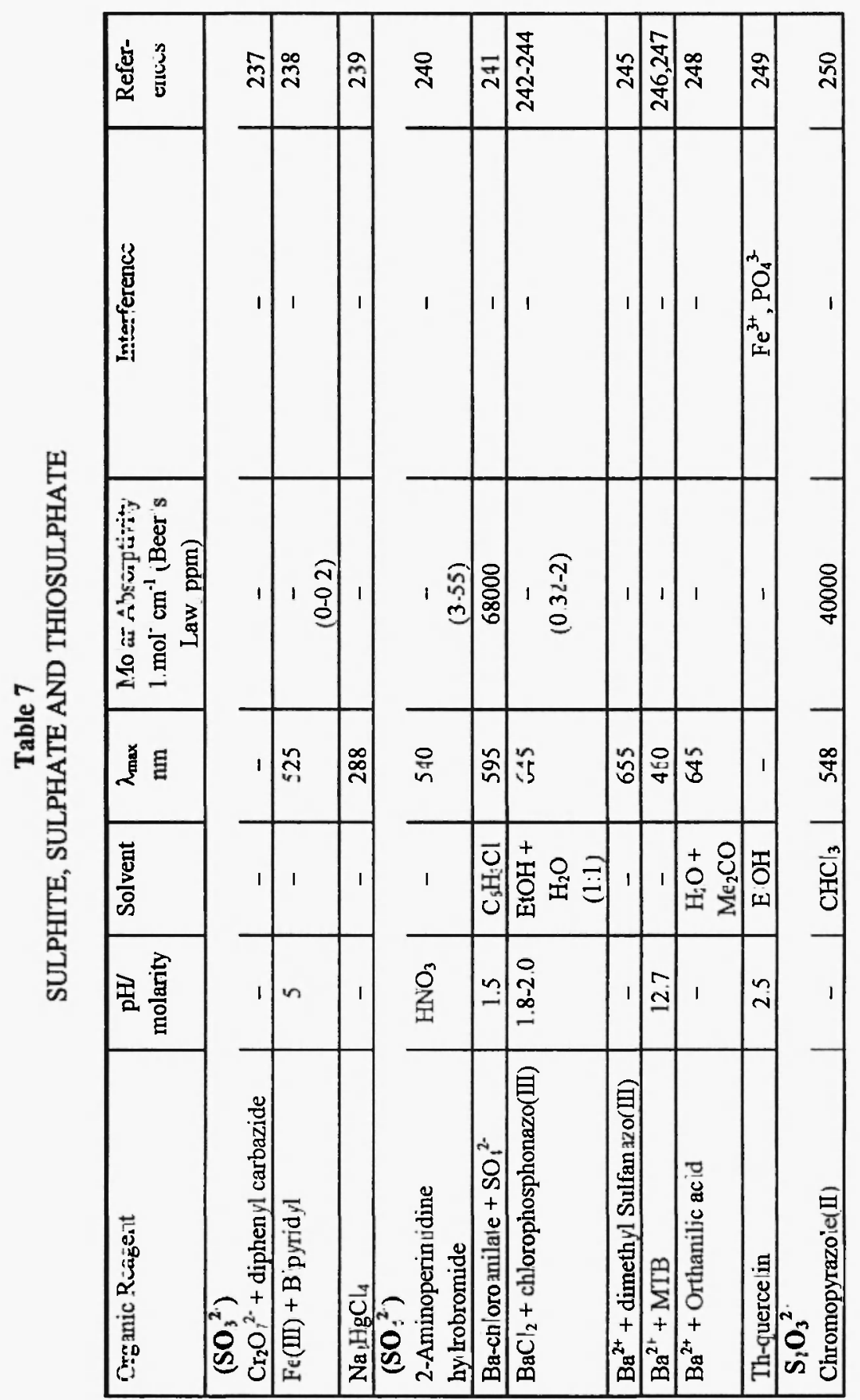




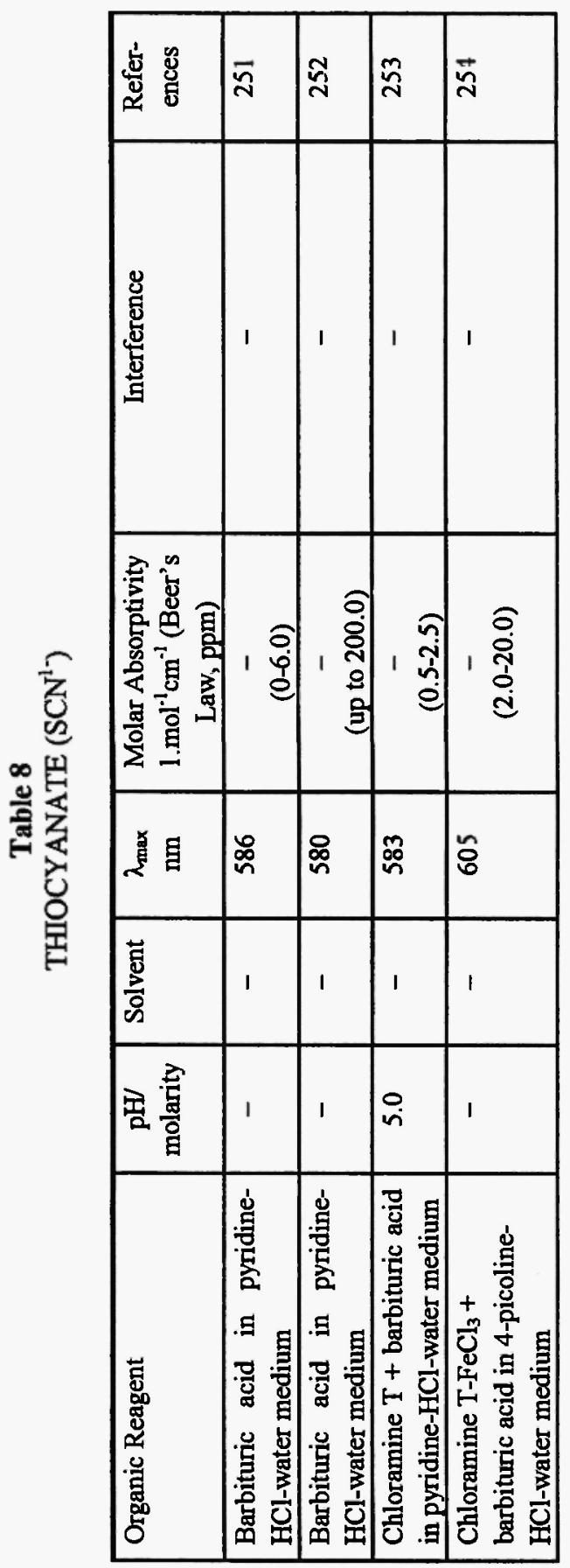




\section{FREQUENTLY USED SPECTROPHOTOMETRIC DETERMINATIONS OF COMMON ANIONS}

\section{Borate}

Borate is extracted as the borate benzohydroxamate-phenylfluorone complex from $20 \%$ tributylphosphate in isoamyl alcohol. The reddish yellow coloured complex has a maximum absorbance at $510 \mathrm{~nm}$ and molar absorptivity $0.5 \times 10^{3} 1 \mathrm{~mol}^{-1} \mathrm{~cm}^{-1}$. It obeys Beer's law in the range of 5-25 ppm $1255 /$.

\section{Bromate}

An equimolar mixture of isonicotinic acid hydrazide and 2,3,5triphenyltetrazolium chloride in dilute hydrochloric acid ( $\mathrm{pH} 0.86$, adjusted with $0.5 \mathrm{NHCl}$ ) gives a pink colour with bromate on heating for $10 \mathrm{~min}$ at $60^{\circ} \mathrm{C}, \lambda_{\max } 480 \mathrm{~nm} / 256 /$.

0 -aminobenzoic acid reacts with bromate in the presence of hydrochloric acid (pH 1.5) to give a reddish brown colour on heating the solution at 80$90^{\circ} \mathrm{C} / 257 /$.

\section{Bromide}

Phenol red upon treatment with hyhpochlorite in the presence of small amounts of bromide forms bromophenol blue. Into a neutral bromide solution add phenol red and borax solution. Add $0.01 \mathrm{~N}$-hypochlorite and allow to stand exactly $4 \mathrm{~min}$ with occasional shaking and add $0.1 \mathrm{~N}$ sodium arsenite followed by acetate buffer $(4.6-4.7 \mathrm{pH})$. The colour obtained will be yellow with less than $1 \mu \mathrm{g}$ of bromide, reddish from 1.5 to $2 \mu \mathrm{g}$ and bluish violet above $2.5 \mu \mathrm{g} / 258 /$.

\section{Chlorate}

Chlorate forms a yellow coloured complex with $o$-toluidine in strong hydrochloric acid solution. The absorbance can be measured at $448 \mathrm{~nm}$ and $490 \mathrm{~nm}$ for low and high concentrations of chlorate ion respectively /259/. 


\section{Chromate}

Diphenylcarbazide reacts with chromium(VI) in acidic medium to give an intense red-violet complex cation, $\lambda_{\max } 540 \mathrm{~nm}$, molar absorptivity $3.14 \mathrm{x}$ $10^{4}$, Beer's Law (0.1 $\left.-0.005 \mathrm{ppm}\right)$. Mo(V) can be masked by oxalate $/ 260 /$.

\section{Citrate}

Citrate can be determined fluorimetrically at $450 \mathrm{~nm}$ by addition to $1: 1$ tungstate flavanal complex, Beer's Law 0-200 ppm /261/.

\section{Cyanide}

The cyanide is determined by reacting it first with excess bromine to give cyanogen and then reacting the cyanogen bromide with a pyridine-benzidine reagent. It also reacts with $p$-phenylenediamine and $0.1 \mathrm{mg}$ cyanide can be determined $/ 262 /$.

\section{Fluoride}

Fluoride gives a stable complex with scandium and, hence, by determining the unreacted scandium, the fluoride content is calculated. Excess scandium is reacted with ethanolic solution of $\mathrm{N}$-phenylbenzohydroxamic acid (PBHA) at $\mathrm{pH} 6.0$ and the scandium-PBHA complex is extracted into isoamyl alcohol. Scandium is determined after adding xylenol orange. Beer's Law for fluoride is obeyed in the range of $0.05-1.5 \mathrm{ppm}$; the molar absorptivity is $1.94 \times 10^{4} \mathrm{I} \mathrm{mol}^{-1} \mathrm{~cm}^{-1} / 263 /$.

\section{Formate}

Reduction of formate by magnesium ribbon to formaldehyde, followed by condensation of the latter with chromotropic acid, enables amounts of formic acid to be determined. 6-Amino-1-naphthol-3-sulphonic acid may also be used $/ 264 \%$.

\section{Hydrogen Peroxide}

Hydrogen peroxide reacts with vanadium( $\mathrm{V})-\mathrm{N}$-phenylbenzohydroxamic acid (PBHA) complexes at $2 \mathrm{M} \mathrm{HCl}$. The colour of the complexes is 
bleached due to formation of a $V(V)$-peroxide complex, decreasing the concentration of vanadium(V)-PBHA complex. The hydrogen peroxide is determined at $520 \mathrm{~nm}$ in the range of $0.5-5.0 \mathrm{ppm} / 255 /$.

\section{Iodate}

Iodate gives a pink colour complex when mixed with an equimolar proportion of isonicotinic acid hydrazide and 2,3,5 triphenyltetrazolium chloride in dilute hydrochloric acid at room temperature. The $\lambda_{\max }$ is $480 \mathrm{~nm}$ $1256 /$.

\section{Nitrite}

Nitrite reacts with salbutamol sulphate in acidic medium, which gives a yellow colour in alkaline solution. Beer's Law is obeyed in the range of 1.8 $27.6 \mathrm{ppm}$ of nitrite with molar absorptivity $1.8 \times 10^{3} 1 \mathrm{~mol}^{-1} \mathrm{~cm}^{-1}$ at $410 \mathrm{~nm}$ $1265 \%$.

\section{Oxalate}

Oxalic acid (in IN sulphuric acid) reacts with indole (heating on water bath at $80-90^{\circ} \mathrm{C}$ for $45 \mathrm{~min}$ ) to form a red or pink-coloured compound, $\lambda_{\max }$ $525 \mathrm{~nm}$, Beer's Law obeyed for 0.050 to $1.00 \mathrm{mg} \mathrm{m}^{-1} / 266 /$.

\section{Perchlorate}

Perchlorate can be determined by extracting it from aqueous solution by $\mathrm{n}$-butyro-nitrite as ferrous 1,10 phenanthroline perchlorate at $\mathrm{pH} 5$. The $\lambda_{\max }$ is $510 \mathrm{~nm}$ and molar absorptivity is $1.08 \times 10^{4} 1 \mathrm{~mol}^{-1} \mathrm{~cm}^{-1} / 267 /$.

\section{Perrhenate}

Perrhenate is first reduced by tin(II) chloride and forms a rhenium dioxime complex with a large excess of $\alpha$-furildioxime. The absorbance of the complex is measured at $532 \mathrm{~nm}$. Beer's Law is obeyed for $20-300 \mathrm{mg}$ of rhenium per $50 \mathrm{ml} / 268 /$. 


\section{Phosphate}

Phosphate is selectively separated from associated elements by reacting it with calcium and extracting excess calcium with $\mathrm{N}$-phenylbenzohydroxamic acid (PBHA) at $\mathrm{pH}$ 11.3. The excess calcium was determined in the UV and visible region and hence the phosphate content was calculated by difference. Beer's Law is obeyed in the range of $0.5-10.0 \mathrm{ppm}$ of phosphate at $340 \mathrm{~nm}$ and $0.25-8.0 \mathrm{ppm}$ at $560 \mathrm{~nm}$ for a fixed amount of calcium (20.0 ppm). It can also be determined by AAS /269/.

\section{Sulphate}

Sulphate reacts with barium chloroanilate at $\mathrm{pH} 4$ in a $50 \%$ ethyl alcohol solution, giving a highly coloured acid chloranilate ion. This has maximum absorbance at $530 \mathrm{~nm} / 270 /$.

\section{Sulphide}

Sulphide is separated from other ions by reacting with mercury and the excess of mercury is determined using $\mathrm{N}$-phenyl-benzohydroxamic acid (PBHA) at $\mathrm{pH}$ 6.8; the sulphide concentration is calculated by difference. Mercury forms a complex with PBHA in ethanol, which is extracted into chloroform. Beer's Law is obeyed for sulphide in the range $0.05-3.0 \mathrm{ppm}$ at $550 \mathrm{~nm}$ for a fixed amount, $20 \mathrm{ppm}$, of mercury /255/.

\section{Thiocyanate}

Thiocyanate is selectively separated from its cation by reaction with mercury(II). The excess mercury(II) is determined using $\mathrm{N}$-phenyl benzohydroxamic acid (PBHA) at pH 6.8 and the thiocyanate concentration calculated. Mercury(II) complexes rapidly with PBHA in ethanol and is further extracted into chloroform. Beer's Law is obeyed for thiocyanate in the range of $0-10 \mathrm{ppm}$ at $550 \mathrm{~nm}$ for a fixed anmount, $20 \mathrm{ppm}$, of mercury(II) /271/. 


\section{REFERENCES}

1. A. Mazaheri, Commun. Soil Sci. Plant Anal., 7, 331 (1976).

2. A. Sippola and R. Ervino, Finn. Chem. Lett., 1977 (4-5), 138.

3. K. Yoshimura, R. Kariya and T. Tarutani, Anal. Chim. Acta, 109, 115 (1979).

4. V.A. Thorpe, J. Assoc. Off., Anal. Chem., 61, 894 (1978).

5. S.G. Samokhvalov and N.A. Tselikova, Khim. Sel'sk. Khoz., 16, 23 (1978).

6. R.A. Edwards, Analyst (London), 105, 136 (1980).

7. A. Cumakov, Agrochemia (Bratislava), 21, 19 (1981).

8. F.J. Krug, J. Mortatti, L.C.R. Pessenda, E.A.G. Zagatto and H. Bergamin Filho, Anal. Chim. Acta, 125, 29 (1981).

9. K. Watanabe, T. Imai, H. Fujii, K. Okada, K. Nakano and M. Take, Hyogo-ken Nogyo Sogo Senta Kenkyu Hokoku, 1981, 29.

10. R. Gabriels and W. Van Keirsbulck, Lab. Pract., 26, 620 (1977).

11. G. Ogner, Commun. Soil Sci. Plant Anal., 11, 1209 (1980).

12. N. Bold and T. Tudor, Rev. Chim. (Bucharest), 33, 854 (1982).

13. J. Lapid, S. Farhi and Y. Koresh, Anal. Lett., 9, 355 (1976).

14. T. Korenaga, S. Motomizu and K. Toei, Analyst (London), 103, (1228), 745 (1978).

15. Z. Skorko-Trybula and Z. Boguszewska, Mikrochim. Acta, 1976 II (3-4), 335.

16. M. Oshima, K. Fujimoto, S. Motomizu and K. Toei, Anal. Chim. Acta, 134, 73 (1982).

17. P.V. Kristalev and M.N. Chelnokova, Zh. Anal. Khim., 29, 1650 (1974).

18. T. Korenaga, S. Motomizu and K. Toei, Analyst (London), 105, 955 (1980).

19. T. Korenaga, S. Motomizu and K. Toei, Anal. Chim. Acta, 120, 321 (1980).

20. K. Kuwada, S. Motomizu and K. Toei, Anal. Chem., 50, 1788 (1978).

21. K. Toei, S. Motomizu, M. Oshima and H. Watari, Analyst (London), 106, 776 (1981).

22. E.W. Grotheer, Anal. Chem., 51, 2402 (1979).

23. H. Kitamura, K. Okawa, Y. Kuge and S. Asada, Kogai to Taigaku, 14, 877 (1978). 
24. E.M. Donaldson, Talanta, 28, 825 (1981).

25. S. Sato and S. Uchikawa, Bunseki Kagaku, 31, 479 (1982).

26. J. Aznarez, A. Bonilla and M.A. Belarra, Rev. Acad. Cienc. Exactas, Fis.-Quim. Nat. Zaragoza, 33, 141 (1978, pub. 1981).

26(a) J. Aznarez-Alduan, A. Bonilla-Polo and J.M. Mir-Marin, Rev. Acad. Cienc. Exactas, Fis.-Quim. Nat. Zaragoza, 35, 105 (1980, pub. 1982).

27. L. Pszonicki and W. Tkacz, Anal. Chim. Acta, 87, 177 (1976).

28. W. Tkacz and L. Pszonicki, Anal. Chim. Acta, 90, 339 (1977).

29. F. Vlacil and K. Drbal, Collect. Czech. Chem. Commun., 40, 2792 (1975).

30. F. Vlacil and K. Drbal, Collect. Czech. Chem. Commun., 41, 1169 (1976).

31. S. Sato and S. Uchikawa, Bunseki Kagaku, 29, 729 (1980).

32. S. Sato and S. Uchikawa, Anal. Chim. Acta, 143, 283 (1982).

33. K. Hiraki, T. Isoda, T. Kitano, H. Hirayama and Y. Nishikawa, Kinki Daigaku Rikogakubu Kenkyu Hokoku, 10, 23 (1975).

34. D.A. Nodirova, M. Musaeva, K.L. Dzhuraeva and S.M. Shamsiev, 2nd Mater. Resp. Nauchno-Tekh. Konf. Molodykh Uch. Pererab. Nefti Neftekhim., 1974; 236.

35. V.A. Nazarenko, G.V. Flyantikova and T.N. Chekirda, Zh. Anal. Khim., 35, 2101 (1980).

36. G.V. Flyantikova, T.N. Chekirda and V.A. Nazarenko, Zh. Anal. Khim., 37, 1982 (1982).

37. V.A. Nazarenko, G.V. Flyantikova and T.N. Chekirda, Zavod. Lab., 47, 19 (1981).

38. P.J. Matthews, Water Res., 8, 1021 (1974).

39. M.C. Mehra and P. O'Brien, Mikrochim. Acta, 1976, II, 603.

40. S.K. Rim and C.H. Han, Punsok Hwahak, 16, 141 (1978).

41. G.L. Narayana, J. Indian Chem. Soc., 54, 417 (1977).

42. B.G. Aleksandrova and K.I. Grigor'eva, 13th Mater. Vses. Nauchn. Stud. Konf. Khim., 1975; 16.

43. A.A. Minin and I.G. Khakhalkina, Proizvod. Pirazolona Anal. Reagenty, Metody Fiz.-Khim. Anal., 1976, 105.

44. A.A. Minin, G.A. Barmina, I.G. Khakhalkina and L.P. Filippova, 4th Org. Reagenty Anal. Khim. Tezizy. Dokl. Vses. Konf., 2, 120 (1976).

45. L. Federgruen and A. Abrao, Report IEA-420, 6 pp. (1976). 
46. I. Paralescu and V.V. Cosofret, Rev. Chim. (Bucharest), 25, 923 (1974).

47. O.A. Efremenko, F.M. Shemyakin, V.M. Gabuchyan and N.A. Timofeeva, Izv. Vyssh. Uchebn. Zaved., Khim. Khim. Tekhnol., 19, 1470 (1976).

48. O.A. Efremenko, F.M. Shemyakin and V.M. Gabuchyan, Izv. Vyssh. Uchebn. Zaved., Khim. Khim. Teckhnol., 20, 466 (1977).

49. G.I. Ilinskaya and N.S. Mudrolyubova, Zh. Anal. Khim., 34, 1306 (1979).

50. E.I. Rudenko and V.A. Popov, Zavod. Lab., 45, 388 (1979).

51. J. Jurkeviciute and M. Malat., Collect. Czech. Chem. Commun., 43, 2855 (1978).

52. E.P. Shkrobot and N.S. Tolmacheva, Zh. Anal. Khim., 31(8), 1491 (1976)

53. L.A. Khristianova, N.I. Udal'tsova and S.S. Soldatova, Gig. Sanit, 11, 88 (1974).

54. E. Dabel, G. Madelmont, S. Peynot and O. Poliakoff, Mikrochim. Acta, I, 441 (1978).

55. R.I. Spirina and E.N. Tulyakov, Khim. Prom-St., Ser.: Metody Anal. Kontrolya Kach. Prod. Khim. Prom. Sti., 1981 (1), 55.

56. H.C. Teng, C.C. Li and H.H. Chu, Fenxi Huaxue, 8, 435 (1980).

57. A.A. Minin, G.A. Barmina and I.G. Khakhalkina, Zh. Anal. Khim., 30, 2196 (1975).

58. V.K. Reddy and D.V. Reddy, Acta Cienc. Indica, Ser. Chem., 8, 48 (1982).

59. G.F. Capitan, F. Salinas and V.J.L. Martinez, An. Quim., 73, 1464 (1977).

60. T. Okutani and S. Utsumi, Bunseki Kagaku, 24, 196 (1975).

61. Y. Suketa, S. Shimokawa and T. Yamamoto, J. Hyg. Chem. (Japan), 21, 89 (1973).

62. W. Likussar, H. Raber, H. Huber and D. Grill, Anal. Chim. Acta, 87, 247 (1976).

63. Z. Marczenko and L. Lenarczyk, Chem. Anal., 21, 151 (1976).

64. N.I. Shuvalov and G.V. Shcherbovich, Deposited Doc. VINITI, 2971-76, 258 (1975, pub. 1976).

65. E.G. Levkov and V.P. Novak, Zavod. Lab., 42, 260 (1976).

66. S. Nishi and Y. Horimoto, Bunseki Kagaku, 26, 757 (1977) 
67. G.A. Kravchenko, Fiz. I. Khim. Metody Issled. Gorn. Porod. I. Mineralov, 1977, 39.

68. V.S. Shkarupa, V.N. Doronina, I.V. Linzina and L.I. Generalova, Metody Anal. Kontrolya Proizvod. Khim. Prom-Sti., 1977 (11), 18.

69. J.C. Landry and F. Cupelin, Mitt. Geb. Lebensmittelunters Hyg., 69, 56 (1978).

70. X. Zhao and W. Liang, Fenxi Hucxue, 9, 497 (1981).

71. X. Zhao and W. Liang, Fenxi Huaxue, 9, 560 (1981).

72. H. Kasuya, T. Tani, H. Inoue, I. Komikai and M. Osawa, Tokyo Gakugei Daigaku Kiyo, Dai-4-Bu, 26, 182 (1974).

73. V.V. Lukachina, A.T. Pilipenko and O.I. Karpova, Zh. Anal. Khim., 32, 1542 (1977).

74. H. Piekacz and E. Kiss, Ocena Hig. Srodkow Kosmet.-Metody Badan, 1978, 4.

75. M.D. Vitalina and V.A. Klimova, Zh. Anal. Khim., 33(X), 1440 (1978).

76. L.M. Yanovski, V.M. Meshchenko and L.A. Mineeva, Stomatologia, 53(X), 74 (1974).

77. E.P. Panteleeva and E.V. Cherepanova, Tr. Leningr. Gos. NauchnoIssled. Proektn. Inst. Osnovn. Khim. Prom-Sti, 1975 (13), 53.

78. E.N. Grekova, E.D. Dukhovnaya and K.A. Martynova, Zavod. Lab., 41, 31 (1975).

79. V.A. Pisarskayaa, Geokhim. Metody Poiskov, Metody Anal., 1977, 194.

80. V.P. Fadeeva and Y.I. Nikonorov, Izv. Sib. Otd. Akad. Nauk. SSSR, Ser. Khim. Nauk., 1980 (5), 101.

81. G.A. Huq and S.B. Rao, curr. Sci., 46, 596 (1977).

82. E.N. Petukhova and S.N. Chirkova, Tr. Ural. Nauchno-Issled. Inst. Chern. Met., 24, 83 (1975).

83. S.B. Savvin, V.P. Dedkova and D.O. Dzhashi, Zh. Anal. Khim., 33, 1159 (1978).

84. D.O. Dzhashi, V.P. Dedkova and S.B. Savvin, Zh. Anal. Khim., 33, 1164 (1978).

85. Y. Tanaka, Y. Saito, K. Nishimura and M. Nakashima, Bunseki Kagaku, 26, 824 (1977).

86. K. Langer and P. Baumann, Fresenius' Z. Anal. Chem., 277, 359 (1975). 
87. T.N. Kukisheva and A.S. Bol'shakova, Radiokhimiya, 18, 428 (1976).

88. S.B. Savvin, V.P. Dedkova and D.O. Dzhashi, Zh. Anal. Khim., 32, 496 (1977).

89. W. Yang, B. Li, X. Wang, S. Xue, S. Zhao and Z. Zhang, Fenxi Shiyanshi, 14(3), 30 (1995).

90. H. Wu, H. Jia and M. Wang, Lanzhao Daxue Xuebao, Ziran Kexueban, 31, 145 (1995).

91. L. Yu, Y. Chen, J. Li, M. Luo and W. Li, Sichaun Daxue Xuebao, Ziran Kexueban, 33, 91 (1996).

92. W.J. Masschelein, M. Denis and R. Ledent, Water Sewage Works, 124, 69 (1977).

93. A.M. Taha and N.A. El-Rabbat, Indian J. Pharm. Sci., 42, 8 (1980).

94. T.K. Margulova, T.S. Shavlova, V.S. Kuznetsov, M.K. Eshchenko, L.P. Poltarakova and V.N. Chvatov, Teploenergetika (Moscow), 1977 (4), 91.

95. Nippon Atomic Industry Group Co., Ltd., Toshiba Corpn., Jpn. Tokyo Koho JP 8154, 582 (CC. G01N21/02), 26 Dec. 1981. Appl. 78/8, 276, 30 Jan., 1978. 5 pp.

97. K.C. James and E. Tsirivas, J. Soc. Cosmet. Chem., 28, 615 (1977).

98. R.M. Sellers, Analyst (London), 105, 950 (1980).

99. M.B. Kats and B.G. Ruderman, Tr. VNIIVS, 1979, 41.

100. C. Matsubara and K. Takamura, Koen Yoshishu-Seitai Seibun no Bunseki Kagaku Shinpojumu, 4th, 1979, 21.

101. C. Matsubara and K. Takamura, J. Pharmacobio-Dyn., 3, S-3, S-29 (1980).

103. C. Matsubara and K. Takamura, Yakugaku Zasshi, 97, 41 (1977).

104. C. Matsubara and K. Takamura, Microchem. J., 22, 503 (1977).

105. M. Veber and L.J. Csanyi, Microchem. J., 22, 238 91977).

106. J. Schneider and L.J. Csanyi, Mikrochim. Acta, 1976, II, 271.

107. C. Matsubura and K. Takamura, Microchem. J., 24, 341 (1979).

108. L.J. Csanyi, Microchem. J., 26, 10 (1981).

109. N. Jie, J. Yang, X. Huang, R. Zhang and Z. Song, Talanta, 42, 1575 (1995).

110. M. Okada, H. Miyata and K. Toei, Analyst (London), 104 (1245), 1195 (1979).

111. K. Toei and T. Kiyose, Anal. Chim. Acta, 88(1), 125 (1977). 
112. T. Zhou and Y. Xie, Int. J. Environ. Anal. Chem., 15(3), 213 (1983).

113. Q. Wu and P. Liu, Fenxi Huaxue, 10(5), 262 (1982).

114. Q. Wu and P. Liu, Talanta, 30(5), 374 (1983).

115. M. Kamaya and T. Murakami, Bunseki Kagaku, 36(3), 204 (1987).

116. S. Flamerz and W.A. Bashir, Microchem. J., 26(4), 586 (1981).

117. T.V. Ramakrishna and N. Balasubramanian, Z. Gesamte Hyg. Ihre Grenzgeb., 30(8), 467 (1984).

118. P.K. Dasgupta, Anal. Lett., 17(A10), 1005 (1984).

119. W.A. Bashir and S. Flamerz, Talanta, 28(9), 697 (1981).

120. R. Hilsheimer and J. Harwig, Can. Inst. Food. Sci. Technol. J., 9(4), 225 (1976).

121. S.T. Sulaiman and D. Amin, Microchem. J., 29(3), 307 (1984).

122. S. Flamerz and W.A. Bashir, Analyst (London), 110(12), 1513 (1985).

123. A. Bhatt and V.K. Gupta, J. Indian Chem. Soc., 57(6), 601 (1980).

124. G. Renner and C. Hopfer, Fresenius' Z. Anal. Chem., 304(5), 405 (1980).

125. M. Sarwar, A. Rashid and S. Wasti, Pak. J. Sci. Ind. Res., 24(1), 18 (1981).

126. H.S. Gowda and K.N. Thimmaiah, Indian J. Chem. Sect. A., 15(8), 763 (1977).

127. J.C. Jimenez Sanchez and J.M. Lemus Gallego, Microchem. J., 32(1), 69 (1985).

128. F. Bosch Reig, J. Martinez Calatayud and R. Pico Puchades, An. Quim., 74(9-10), 1256 (1978).

129. M. Nakamura and A. Murata, Analyst (London), 104 (1243), 985 (1979).

130. M. Nakamura and T. Mazuka, Anal. Lett., 16 (A11), 811 (1983).

131. M. Nakamura, T. Mazuka and M. Yamashita, Anal. Chem., 56(2), 2242 (1984).

132. B.P. Zhantalai, Z.I. Sukhareva and V.S. Gudz, Khim. Prom-st. Ser: Azotn. Prom-st., 1979 (4), 63.

133. A. Gonzalez-Portal, C. Baluja-Santos and M.L. Reija-Brualla, Quim. Anal., 30(5), 289 (1976).

134. L. Hainberger and J. Nozaki, Mikrochim. Acta, 1979, 11(3-4), 187.

135. S. Sunita and V.K. Gupta, Int. J. Environ. Anal. Chem., 19(1), 11 (1984). 
136. G.F. Capitan, C.M. Roman and F. Ales-Barrero, Bol. Soc. Quim. Peru, 43(1), 1 (1977).

137. C.M. Roman, A. Fernandez-Gutierrez and M.C. Mahedero, Bol. Soc. Quim. Peru, 43(1), 16 (1977).

138. G. Balica and H. Pirvanescu, Rev. Chim. (Bucharest), 28(1), 1004 (1977).

139. J. Nair and V.K. Gupta, Anal. Chim. Acta, 111, 311 (1979).

140. S.A. Rahim, N.A. Fakhri and W.A. Bashir, Microchem. J., 28(4), 479 (1983).

141. C.P. Joshi, H.O. Mehta, J. Franco and N.K. Patel, Met. Miner. Rev., 18(2), 48 (1979).

142. A.K. Baveja and V.K. Gupta, Fert. Technol., 19(1-2), 80 (1982).

143. A.K. Baveja, J. Nair and V.K. Gupta, Analyst (London), 106(1266), 955 (1984).

144. J. Maly and M. Kosikova, Vodni Hospod B, 33(5), 137 (1983).

145. D. Amin, Analyst (London), 111(11), 1335 (1986).

146. G. Knittel, D. Ertel and P. Dressler, Kernforschungs-Zentrum, Karlsruhe Ber. $K F K-2263,11$ (1976).

147. Y. Kaneda and M. Iwaida, Shokuhin. Eiseigaku. Zasshi, 18(5), 470 (1977).

148. R. Reisfeld, S. Levi and W.J. Levene, Anal. Chim. Acta, 84(1), 135 (1976).

149. W. Rechenberg, Zem.-Kalk-Gips., 219(6), 254 (1976).

150. R.B. Lew, Analyst (London), 102 (1215), 476 (1977).

151. K. Puttanna and E.V.S.P. Rao, Z. Pflanzenernaehr. Bodenkd, 149(5), 517 (1986).

152. A. Chaube, A.K. Baveja and V.K. Gupta, Anal. Chim. Acta, 143, 273 (1982).

153. Fu-Pao Tsao and A.L. Underwood, Anal. Chim. Acta, 136, 129 (1982).

154. A. Chaube, A.K. Baveja and V.K. Gupta, Talanta, 31(5), 391 (1984).

155. W.A. Bashir, S. Flamerz and S.K. Ibrahim, Int. J. Environ. Anal. Chem., 15(2), 65 (1983).

156. H.S. Gowda and K.N. Thimmaiah, Microchem. J., 23(3), 291 (1978).

157. E. Agullo, B.S. Fernandez Band, E. Rubio and A.L. Allan, An. Quim. Ser. B, 80(3), 494 (1984). 
158. A. Bhatt and V.K. Gupta, J. Indian Chem. Soc., 57(11), 1056 (1980).

159. J. Gabbay, Y. Almog, M. Davidson and A.E. Donagi, Analyst (London), 102(1214), 371 (1977).

160. H. Nakamura, S. Arieda and I. Nakamori, Bunseki Kagaku, 25(6), 404 (1976).

161. P. Bruno, M. Casell and A. Traini, Anal. Chim. (Rome), 74(3-4), 321 (1984).

162. P.N. Bhatt and Y.K. Agrawal, Anal. Lett., 19(23-24), 2231 (1986).

163. T. Fujinaga, T. Hori and T. Kyoto, Bunseki Kagaku, 28(4), 222 (1979).

164. R. Borisova and E. Mitropolitska, Talanta, 26(7), 543 (1979).

165. E. Mitropolitska and R. Borisova, Fresenius' Z. Anal. Chem., 294(4), 285 (1979).

166. R. Borisova and E. Mitropolitska, Dokl. Bolg. Akad. Nauk., 33(11), 1497 (1980).

167. N.A. Ivanov, Zh. Anal. Khim., 32(9), 1688 (1977).

168. S. Motomizu, Bunseki, 1983 (12), 961.

169. F. Bet-Pera, A.K. Srivastava and B. Jaselskis, Anal. Chem., 53(6), 861 (1981).

170. V.K. Reddy and D.V. Reddy, J. Indian Inst. Sci. Sec. B, 63 (1), 211 (1982).

171. Y. Saito, M. Mifune, K. Ikegami, K. Okazaki, J. Odo and Y. Tanaka, Chem. Pharm. Bull., 33(8), 3381 (1985).

172. G. Berti, P. Fossati, G.V. Malzi d'Eril, G. Tarenghi and C. Musitelli, Clin. Chem. (Winston-Salem, N.C.), 33(2), 312 (1987).

173. F. Lagerloef, Caries Res., 16(4), 329 (1982).

174. J. Shida and T. Matsuo, Bull. Chem. Soc. (Jpn.), 53(1), 2868 (1980).

175. A. Jaroschek, Z. Anal. Chem., 282(5), 460 (1976).

176. N.K. Murty and A.V. Suryanarayana, J. Ind. Chem. Soc., 59(9), 1113 (1982).

177. B.D. Bell, W.D. Bell and R.M. Hurley, Microchem. J., 21(3), 309 (1976).

178. M.G. Kiperman and L.E. Erofeeva, Zavod Lab., 43(4), 418 (1977).

179. E.S. Beskova, G.I. Zhuravlev and L.M. Morozova, Zh. Anal. Khim., 31(8), 1572 (1976).

180. E. Kitazume, N. Shibata and N. Hashimoto, Anal. Chim. Acta, 91(2), 375 (1977). 
181. K. Yoshimura, M. Ishii and T. Tarutani, Anal. Chem., 58, 591 (1986).

182. N. Ichinose, S. Yamada, N. Sakurai, T. Fujiyama and N. Masuda, Fresenius' Z. Anal. Chem., 293(1), 23 (1978).

183. N.A. Ivanov, N.G. Todorova and D.B. Boikova, Dokl. Bolg. Akad. Nauk, 30(2), 265 91977).

184. L.A. Demina, N.N. Mazepova, S.I. Zhdanov and B.L. Podolskaya, Zh. Anal. Khim., 32(6), 1138 (1977).

185. F.Y. Mirzoyan, V.M. Tarayan and A.A. Petrosyan, Ukr. Khim. Zh., 46(9), 995 (1980).

186. N. Potman and L. Lijklema, Water Res., 13(8), 801 (1979).

187. Y. Zheng and Z. Wang, Fenxi Huaxue, 11(8), 596 (1983).

188. D.T. Burns and J.J. McAllister, Anal. Chim. Acta, 128, 257 (1981).

189. V.M. Shkinev, B.Ya. Spivakov, V.A. Orlova, T.M. Malyutina, T.I. Kirillova and Yu.A. Zolotov, Zh. Anal. Khim., 33(5), 922 (1978).

190. N.K. Murty, A. Suryanarayana and G. Rambabu, Ind. J. Chem. Chem. Sect. A, 21(9), 940 (1982).

191. K. Matsuhisa and K. Ohzeki, Analyst (London), 111(6), 685 (1986).

192. V. Ramasubramanian and K.S. Narayan, Indian J. Technol., 17(9), 355 (1979).

193. M. Namiki and K. Hirokawa, Bunseki Kagaku, 25(10), 715 (1976).

194. J. Shida, S. Kakizaki, Y. Hozumi, A. Itoh and T. Matsuo, Bull. Chem. Soc. Jpn., 56(2), 633 (1983).

195. S. Motomizu and M. Oshima, Analyst (London), 112(3), 295 (1987).

196. C. Matsubara, Y. Yamamoto, G. Odaka and K. Takamura, Bunseki Kagaku, 36(3), 189 (1987).

197. C. Matsubara, M. Takahashi and K. Takamura, Yakugaku Zasshi, 105(2), 1155 (1985).

198. S. Motomizu, T. Wakimoto and K. Toei, Talanta, 31(4), 235 (1984).

199. S. Motomizu, T. Wakimoto and K. Toei, Analyst (London), 108(1284), 361 (1983).

200. T. Matsuo, J. Shida and W. Kurihara, Anal. Chim. Acta, 91(2), 385 (1977).

201. P.L. Buldini and D. Sandrini, Anal. Chim. Acta, 98(2), 401 (1978).

202. M.N. Ptushkina, L.I. Lebedeva and I.P. Kravtsova, Zh. Anal. Khim., 33(2), 308 (1978).

203. C. Sanchez-Pedreno, M. Hernandez-Cordoba and I. Lopez-Garcia, An. Quim. Ser. B, 79(3), 440 (1983). 
204. S. Motomizu, T. Wakimoto and K. Toei, Anal. Chim. Acta, 138, 329 (1982).

205. K. Matsuhisa, K. Ohzeki and T. Kambara, Bull. Chem. Soc. Jpn., 54(9), 2675 (1981).

206. A.A. Baikor and S.M. Araeva, Anal. Biochem., 116(1), 1 (1981).

207. K. Ohashi, T. Enomoto and K. Yamamoto, Bull. Chem. Soc. Jpn., 54(6), 1882 (1981).

208. S.M. Hassan and F.B. Salem, Anal. Lett, 20(1), 1 (1987).

209. M. Hernandez-Cordoba, I. Lopez-Garcia and C. Sanchez-Pedreno, Quim. Anal., 3(4), 319 (1984).

210. H. Narasaki, K. Ogawa and K. Tsujimoto, Bunseki Kagaku, 28(3), 195 (1979).

211. N.N. Nikolov, Pochvozn, Agrokhim., 11(6), 32 (1976).

212. E.I. Shelikina, M.A. Chernysheva and V.P. Antonovich, Zovod. Lab., 42(9), 1057 (1976).

213. R. Lagunas and G. Delafuente, Mikrochim. Acta, 1979, II (3-4), 181.

214. N.B. Roberts, Clin. Chem. (Winston-Salem N.C.), 24(10), 1836 (1978).

215. M.A. Munoz, M. Balon and C. Fernandez, Clin. Chem. (WinstonSalem N.C.), 29(2), 372 (1983).

216. L.I. Ganago and N.N. Ishchenko, Zh. Anal. Khim., 34(3), 481 (1979).

217. N.A. Ivanov, D.B. Boikova and N.G. Todorova, Dokl. Bolg. Akad. Nauk., 30(5), 731 (1977).

218. L.I. Lebedeva and D.N. Nikolaeva, Zh. Anal. Khim., 37(2), 260 (1982).

219. K.N. Nikolaeva and L.I. Lebedeva , Fiz. Khim., 22(4), 112 (1992).

220. F.V. Mirzoyan, N.P. Sarkisyan and V.M. Tarayan, Zh. Anal. Khim., 41(9), 1601 (1986).

221. K.S. Subramanian and A. Corsini, Can. J. Chem., 56(13), 1729 (1978).

222. O.K. Chkanikova, V.Yu. Krivtsova and E.N. Dorokhova, Zh. Anal. Khim., 34(6), 1207 (1979).

223. A. Sakuragawa, Bunseki Kagaku, 35(11), 926 (1986).

224. Z. Song, Lihua Jianyan, Huaxue Fence, 32, 48 (1996).

225. B. Bai and Y. Jiao, Shanghai Youse Jinshu, 15, 157 (1994). 
226. H.N. Bajpei, C.S.P. Iyer and M.S. Das, Anal. Chim. Acta, 72, 423 (1974).

227. T. Sato and T. Kuroha, Bunseki Kagaku, 23, 1236 (1974).

228. C. Rozycki and W. Suszczewski, Chem. Anal. (Warsaw), 19, 1231 (1974).

229. E.A. Pronina, V.V. Fedotova and D.M. Maiorov, Neftepererab. Nefte Khim. (Moscow), 1974 (8), 40.

230. L.E. Thorn, R.G. Bryan and G.R. Waterbury, USAEC Report, La5884, $6 \mathrm{pp}, 1975$.

231. A.M. Krichevskaya and A.A. Fedorov, Zh. Anal. Khim., 32, 1149 (1977).

232. T. Stan, V. Antonescu, E. Stefanescu and E. Feraru, Farmacia (Bucharest), 27, 85 (1979).

233. K. Narita, M. Taniguchi, N. Ota and R. Morooka, Tetsu to Hagane, 67, 2724 (1981).

234. L.S. Tsebrii, V.Z. Orlova, L.A. Belyantseva and E.I. Vail, Metody Anal. Kontrolya Proizvod. Khim. Prom-Sti, 10, 90 (1977).

235. N.M. Lukovskaya and N.L. Anatienko, Ikr. Khim., 14, 44, 199 (1978).

236. R.J. Cassella and R.E. Santelli, Quim. Nova, 18, 536 (1995).

237. A.A. Tumanov, N.M. Shakhverdi, G.A. Miklina, A.M. Tsirlin, G.M. Naumchik and V.B. Vorobev, Zavod. Lab., 45, 796 (1979).

238. T. Stan, V. Antonescu, D. Balalau, E. Stefanescu and E. Maftei, Farmacia (Bucharest), 27, 141 (1979).

239. Y. Arikawa, T. Ozawa and I. Iwasaki, Bunseki Kagaku, 24, 497 (1975).

240. S.F. Mu, T.Y. Chi, K.N. Liu and S.C. Hung, Huanjing Kexue, 4, 41 (1979).

241. T. Murakani, M. Kamaya and T. Akazawa, Bunseki Kagaku, 29, 483 (1980).

242. V.P. Fadeeva and N.F. Zaslavskaya, Izv. Sib. Otv. Akad. Nauk. SSSR, Ser. Khim. Nauk, 3, 155 (1976).

243. V.G. Baranova, N.K. Loginova and R.A. Kuznetsova, Prom-St. Sint. Kauch., 1976 (8), 16.

244. A.I. Busev, V.M. Pryakhina, A.I. Boiko, V.V. Bigma, T.A. Pampushko and A.A. Shcherbina, Zavod. Lab., 48, 20 (1982).

245. U. Bartels and T. Pham, Fresenius' Z. Anal. Chem., 310, 13 (1982). 
246. V.C. Bittencourt, L.F. Batista, M.N. Gurgel and D.A. Cordeiro, Rev. Bras. Cienc. Solo, 2, 184 (1978).

247. Z. Urner and L. Sucha, Sb. Vys. Sk. Chem.-Technol. Praze, Anal. Chem., H14, 197 (1979).

248. S.B. Savvin, V.P. Dedkova and T.G. Akimova, Geokhim. Anal. Metody Izuch Veshchestv. Sostava Osad. Porod Rud, 2, 111 (1974).

249. D.P. Shcherbov and A.I. Ivankova, Tezisy Dokl. Vses, Soveshch. Lyumin, 22nd, 38 (1975).

250. O.A. Efremenko, O.B. Esenina, N.A. Ovesnova and F.M. Shemyakin, Izv. Vyssh. Uchebn. Zaved., Khim. Technol., 22, 927 (1979).

251. A. Sharma and RJ. Thibert, Mikrochim. Acta, 1985, 1 (5-6), 357.

252. P. Lundquist, J. Martensson, B. Serbo and S. Ohman, Clin. Chem. (Winston-Salem N.C.), 25(5), 678 (1979).

253. T. Toida, S. Tanabe and T. Imanari, Chem. Pharm. Bull., 29 (12), 3763 (1981).

254. A. Aleksiev, B. Stefanov and M. Angelova, Gig. Sanit., 6, 68 (1986).

255. Y.K. Agrawal (unpublished work).

256. M.H. Hashmi, H. Ahmad, A. Rashid and F. Azam, Anal. Chem., 36, 2471 (1964).

257. M.H. Hashmi, A. Ayaz and H. Ahmad, Anal. Chem., 36, 2029 (1964).

258. V.A. Stenger and I.M. Kolthoff, J. Am. Chem. Soc., 57, 831 (1935).

259. P. Urone and E. Bonde, Anal. Chem., 32, 1666 (1960).

260. B.E. Saltzman, Anal. Chem., 24, 1016 (1952).

261. J.C. Guyon and J.Y. Marks, Mikrochim. Acta, 1969, 731.

262. J.L. Royer, J.E. Twichell and S.M. Muir, Anal. Lett., 6, 619 (1973).

263. P.N. Bhatt and Y.K. Agrawal, Intern. J. Environ. Anal. Chem., 39, 411 (1990).

264. E. Sawicki, T.R. Hauser and S. McPherson, Anal. Chem., 34, 1460 (1962).

265. Y.K. Agrawal and P.N. Bhatt, Anal. Lett., 21, 2307 (1988).

266. J. Bergerman and J.S. Elliot, Anal. Chem., 27, 1014 (1955).

267. J.S. Fritz, J.E. Abbink and P.A. Campbell, Anal. Chem., 36, 2123 (1964).

268. V.W. Meloche, R.L. Martin and W.H. Webb, Anal. Chem., 29, 257 (1957).

269. Y.K. Agrawal and P.N. Bhatt, Anal. Lett., 19, 2231 (1986). 
270. R.J. Bertolacini and J.E. Barney, Anal. Chem., 29, 281 (1957).

271. Y.K. Agrawal and P.N. Bhatt, Analyst, 112, 1767 (1987). 